\title{
Oxidative Reduction of Glove Box Wipers with a Downdraft Thermal Oxidation System
}

\author{
M. R. Phelps \\ W. A. Wilcox
}

April 1996

Prepared for

Westinghouse Hanford Company and the U.S. Department of Energy

under Contract DE-AC06-76RLO 1830

Pacific Northwest National Laboratory

Operated for the U.S. Department of Energy

by Battelle

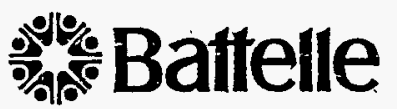

DISTAIBUTION OF THIS DOCUMENT IS LNLMMAED 


\section{DISCLAIMER}

This report was prepared as an account of work sponsored by an a'gency of the United States Government. Neither the United States Government nor any agency thereof, nor Battelle Memorial Institute, nor any of their employees, makes any warranty, express or implied, or assumes any-legal liability or responsibility for the accuracy, completeness, or usefulness of any information, apparatus, product, or process disclosed, or represents that its use would not infringe privately owned rights. Reference herein to any specific commercial product, process, or service by trade name, trademark, manufacturer, or otherwise does not necessarily constitute or imply its endorsement, recommendation, or favoring by the United States Government or any agency thereof, or Battelle Memorial Iristitute. The views and opinions of authors expressed herein do not necessarily state or reflect those of the United States Government or any agency thereóf.

\section{PACIFIC NORTHWEST NATIONAL LABORATORY operated by \\ BATTELLE \\ for the \\ UNITED STATES DEPARTMENT OF ENERGY under Contract DE-AC06-76RLO 1830}

Printed in the United States of America

Available to DOE and DOE contractors from the

Office of Scientific and Technical Information, P.O/ Box 62, Oak Ridge, TN 37831; 1 prices available from (615) 576-8401.

- Available to the public from the National Technical Information Service, U.S. Department of Commerce, 5285 Port Royal Rd., Springfield, VA 22161 


\section{Oxidative Reduction of Glove Box Wipers with a Downdraft Thermal Oxidation System}

M. R. Phelps

W. A. Wilcox

April 1996

Prepared for

Westinghouse Hanford Company and the U.S. Department of Energy under Contract DE-AC06-76RLO 1830

Pacific Northwest National Laboratory

Richland, Washington 99352 



\section{Summary}

Wipers (rags) used for decontamination and glove box cleanup in the Plutonium Finishing Plant often become soaked with acid and plutonium-rich solutions. After use, these wipers are rinsed in a dilute $\mathrm{NaOH}$ solution and dried, but the formation of unstable nitrates and the hydrogen gas caused by hydrolysis are concerns that still must be addressed. This report gives the results of testing with a small downdraft thermal oxidation system that was constructed by Pacific Northwest National Laboratory to stabilize glove wiper waste, reduce the waste volume, and reclaim plutonium.

Proof-of-principle testing was conducted with eight runs using various combinations of rag moisture and chemical pretreatment. All runs went to planned completion. Results of these tests indicate that the thermal oxidation system has the potential for providing significant reductions in waste volume. Weight reductions of 150:1 were easily obtainable during this project. Modifications could result in weight reductions of over 200:1, with possible volume reductions of 500:1. 



\section{Contents}

Summary $\ldots \ldots \ldots \ldots \ldots \ldots \ldots \ldots \ldots \ldots \ldots \ldots \ldots \ldots \ldots \ldots \ldots \ldots$ iii

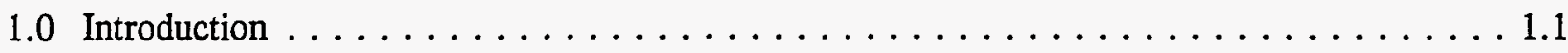

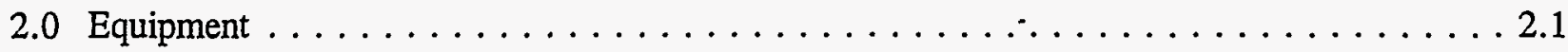

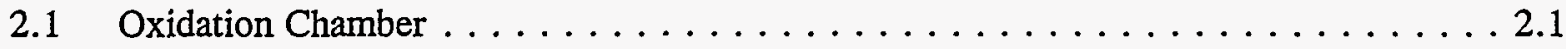

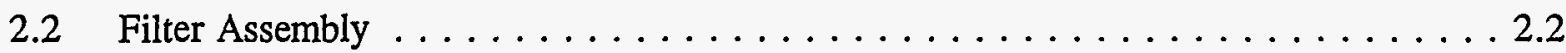

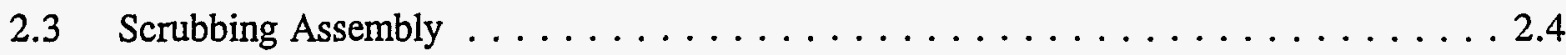

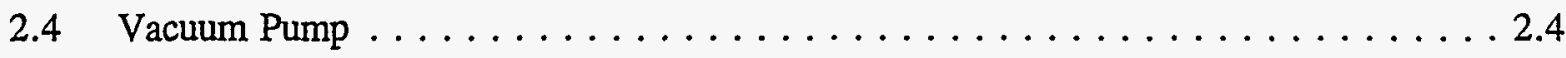

3.0 Experimental Procedures and Results $\ldots \ldots \ldots \ldots \ldots \ldots \ldots \ldots \ldots \ldots \ldots \ldots \ldots \ldots \ldots \ldots$

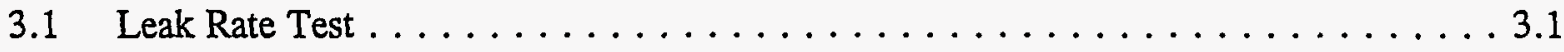

$3.2 \mathrm{CHN}$ Analysis of Glove Box Wipers $\ldots \ldots \ldots \ldots \ldots \ldots \ldots \ldots \ldots \ldots \ldots$

3.3 Experimental Runs $\ldots \ldots \ldots \ldots \ldots \ldots \ldots \ldots \ldots \ldots \ldots \ldots \ldots \ldots \ldots \ldots$

3.3.1 Run \#1: Dry Rags, Loosely Packed $\ldots \ldots \ldots \ldots \ldots \ldots \ldots \ldots \ldots \ldots \ldots$

3.3.2 Run \#2: Dry Rags, Tightly Packed . . . . . . . . . . . 3.3

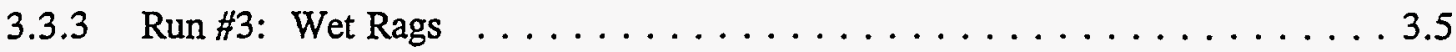

3.3.4 Run \#4: Simulated Loading with $\mathrm{HNO}_{3}, \mathrm{Na}_{2} \mathrm{CO}_{3}$, and $\mathrm{Fe}\left(\mathrm{NO}_{3}\right)_{3} \ldots \ldots .6$

3.3.5 Run \#5: Rags Soaked in $\mathrm{Fe}\left(\mathrm{NO}_{3}\right)_{3}$ and Water $\ldots \ldots \ldots \ldots . . \ldots \ldots$

3.3.6 Run \#6: Dry Rags, Catalyst Placed in the 1-in. Line from the Oxidation Chamber Assembly to the Filter Assembly . . . . . . . . . . 3.11

3.3.7 Run \#7: Dry Rags, Catalyst Placed in Bottom of Conical Reducer . . . . . 3.13

3.3.8 Run \#8: Catalyst, Rags Soaked in $\mathrm{Fe}\left(\mathrm{NO}_{3}\right)_{3}$ and Rinsed in Water . . . . 3.14

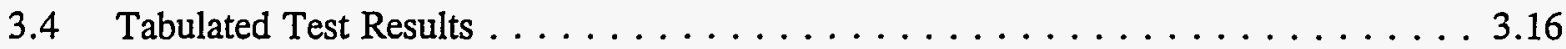

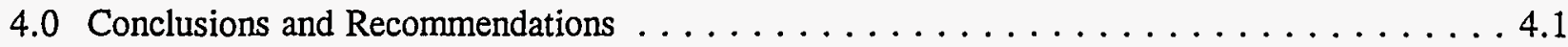




\section{Figures}

2.1 Instrument Points and Flow Diagram $\ldots \ldots \ldots \ldots \ldots \ldots \ldots \ldots \ldots \ldots \ldots \ldots$

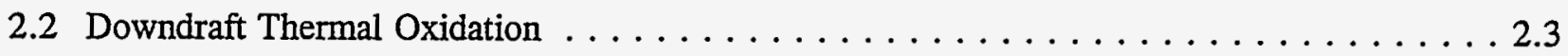

\section{Tables}

3.1 CHN Analysis $\ldots \ldots \ldots \ldots \ldots \ldots \ldots \ldots \ldots \ldots \ldots \ldots \ldots \ldots \ldots \ldots \ldots \ldots$

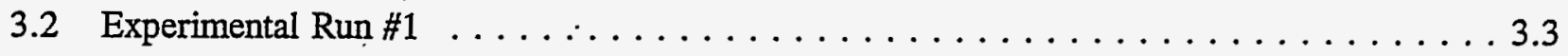

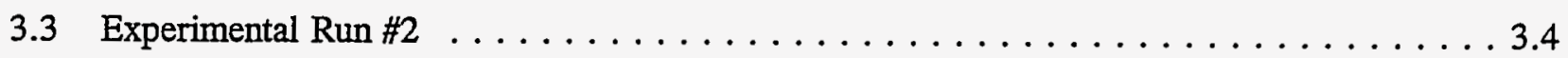

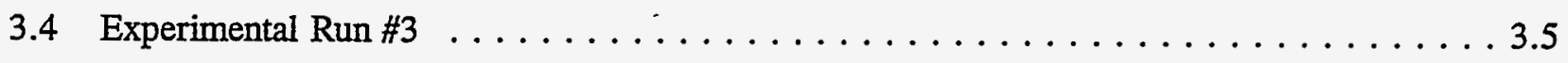

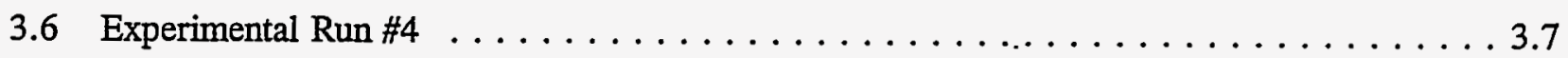

3.7 Average Gas Analysis of Experimental Run $\# 4 \ldots \ldots \ldots \ldots \ldots \ldots \ldots \ldots$

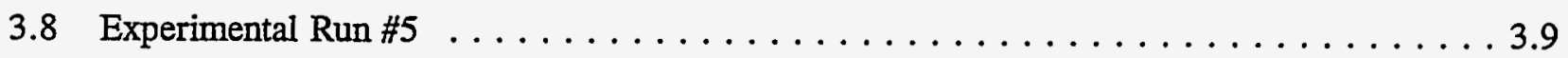

3.9 Average Gas Analysis of Experimental Run $\# 5 \ldots \ldots \ldots \ldots \ldots \ldots$

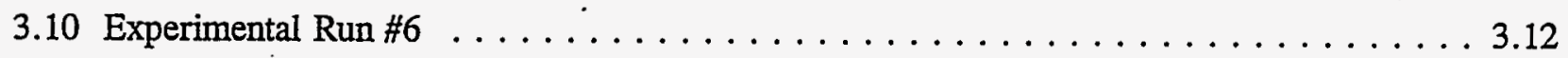

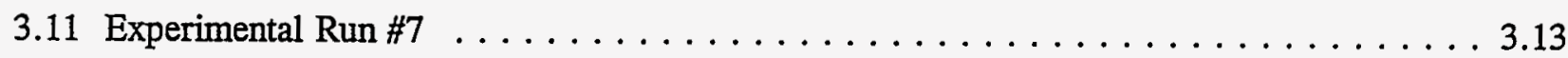

3.12 Average Gas Analysis for Experimental Run $\# 7 \ldots \ldots \ldots \ldots \ldots \ldots \ldots \ldots$

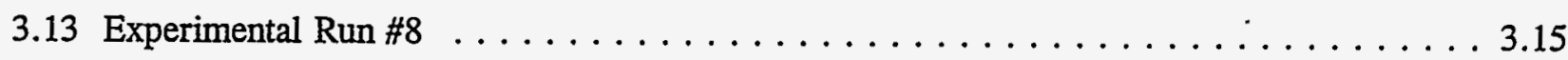

3.14 Average Gas Analysis of Experimental Run $\# 8 \ldots \ldots \ldots \ldots \ldots \ldots \ldots \ldots$

3.15 Tabulated Results of Experimental Runs $\# 1$ Through $8 \ldots \ldots \ldots \ldots \ldots . \ldots \ldots$

\section{Temperature Profile Graphs}

Downdraft Gasifier Run $\# 1 \quad \ldots \ldots \ldots \ldots \ldots \ldots \ldots \ldots \ldots \ldots$

Downdraft Gasifier Run $\# 2 \ldots \ldots \ldots \ldots \ldots \ldots \ldots \ldots \ldots$

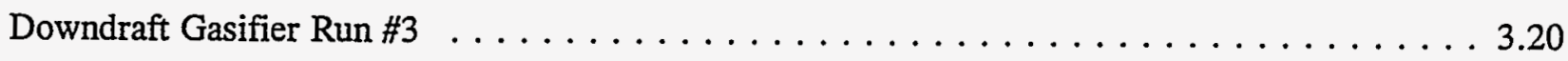

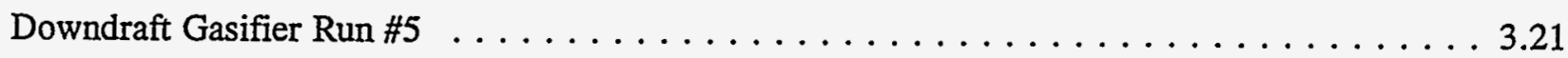

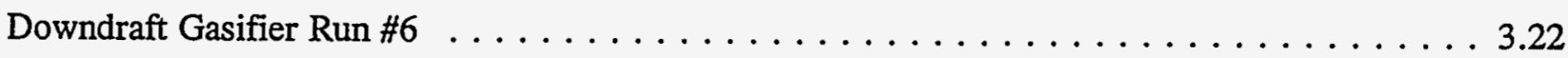

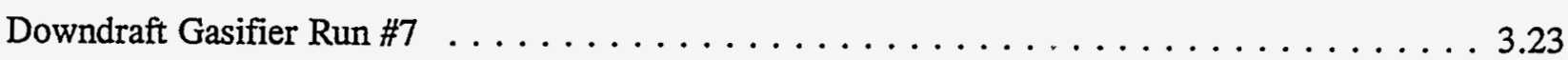

Downdraft Gasifier Run $\# 8$. . . . . . . . . . . . . . . . . . . 3.24 


\subsection{Introduction}

Wipers (rags) are often used for decontamination and glove box cleanup in the Plutonium Finishing Plant (PFP) at the U.S Department of Energy's Hanford Site. During these operations, the wipers frequently become soaked with acid and plutonium-rich solutions. Although the wipers are rinsed in a dilute $\mathrm{NaOH}$ solution and dried after use, they are still considered a hazard. Principal concerns are the formation of unstable nitrates and the hydrogen gas caused by hydrolysis.

Thermal oxidation is one method considered for addressing these concerns. With an efficiently operating oxidation unit, the major benefits that could be realized include:

1. stabilization of glove box wiper waste to a safe form

2. large reduction in the waste volume

3. a method of collecting plutonium in a concentrated form, reducing equipment size and chemical volume required for recovery.

In 1979, a small thermal oxidation system was designed, fabricated, and tested for the Z-plant by Rockwell Hanford Operations with uncontaminated rags in the PFP pilot plant laboratory. Eleven runs were made using various combinations of rag moisture, air flow, and chemical pretreatment. Although only six of the runs went to planned completion, test results indicated that the potential for waste reduction is significant, with waste volume reductions of 100:1 easily obtainable. Changing priorities delayed issuing the test results until 1987. In the interim, the original system was disassembled, resulting in loss of some of the components.

In October 1991, Pacific Northwest National Laboratory ${ }^{(a)}$. constructed a small downdraft thermal oxidation system for the PFP (now operated by Westinghouse Hanford Company). Proof-ofprinciple (Phase I) testing of the oxidation chamber was completed in April 1992. Eight runs were made using various combinations of rag moisture and chemical pretreatment. All runs went to planned completion, with weight reductions of 150:1 easily obtainable. The experimental results and procedures are discussed in this report, along with recommendations for further development.

(a) Operated for the U.S. Department of Energy by Battelle under Contract DE-AC06-76RLO 1830. 


\section{.}




\subsection{Equipment}

The thermal oxidation system consists of an oxidation chamber assembly, a filter assembly, scrubbing assembly, and two catch pots (see Figure 2.1). The oxidation chamber assembly consists of the chamber, grate, catch pot, and two ceramic fiber heaters. Instrumentation for the oxidation chamber assembly includes a flow meter to measure air flow into the chamber, a pressure gauge to measure vacuum pressure in the chamber, and thermocouples to measure temperatures within the chamber and the skin temperature of the chamber's body. A catch pot is located just below the main oxidation chamber body for collecting noncombustibles. The filter assembly houses two 5-micron, 304 stainless steel (SS) tubular filters, 10 in. long, and a catch pot for collecting particulates.

Instrumentation for the filter assembly includes a differential pressure gauge to measure pressure drop across the filters and a thermocouple to monitor air temperature inside the filters. The scrubbing assembly includes a condenser and a back siphon trap. A differential pressure gauge measures the pressure drop across the scrubbing assembly.

\subsection{Oxidation Chamber}

The main oxidation chamber (see Figure 2.2) is constructed of Schedule 40, 304 or 316 SS, 6-in. piping. Heat is supplied by two ceramic clamshell heaters strapped to the outer skin of the oxidation chamber body. Air is supplied through two 3/8-in. SS tubes, which are wrapped around the chamber body in the space between the chamber's skin and the clamshell heaters. The air supply tubes enter the oxidation chamber tangentially, 180 degrees apart from each other, at the top of the internal grate. The grate is constructed of $1 / 8$ in. $x 1$ in. SS flat iron strips, which are separated by 5/16-in. SS washers. The distance between each strip is $3 / 4$ in. A catch pot, connected to the chamber body with a 6 in. $x$ 1 in. conical reducer, is located below the grate to catch ash and other noncombustibles.

A dry test meter measures air flow into the oxidation chamber, and an absolute pressure gauge measures inside pressure. Air is drawn through the system with a Model 1397 Welch vacuum pump connected to the scrubbing assembly. Thermocouples in the chamber measure the temperatures above and below the grate as well as the temperature inside the rag container (a round carton similar to $1 / 2$-gal round ice cream cartons). Another thermocouple located in the space between a ceramic fiber heater and the chamber's skin indicates the temperature of the exterior wall.

The oxidation chamber is protected from overpressure with a spring-loaded, 6-in. SS blank flange attached at the top of the oxidation chamber body. The blank flange is removed prior to each run to load the rag container into the chamber and onto the grate. The blank flange is then reinstalled by slightly compressing each of four springs around the four bolts attaching the blank flange to the oxidation chamber body. A premeasured gauge is used to determine compressed spring length such that the blank flange shoul ${ }^{1}$. it and relieve internal pressure at 35 psig.

Power to the ceramic heaters is controlled through a single variac. To limit the number ofvariables for each run, the variac was always set to supply a current of 19 amps to each heater. 


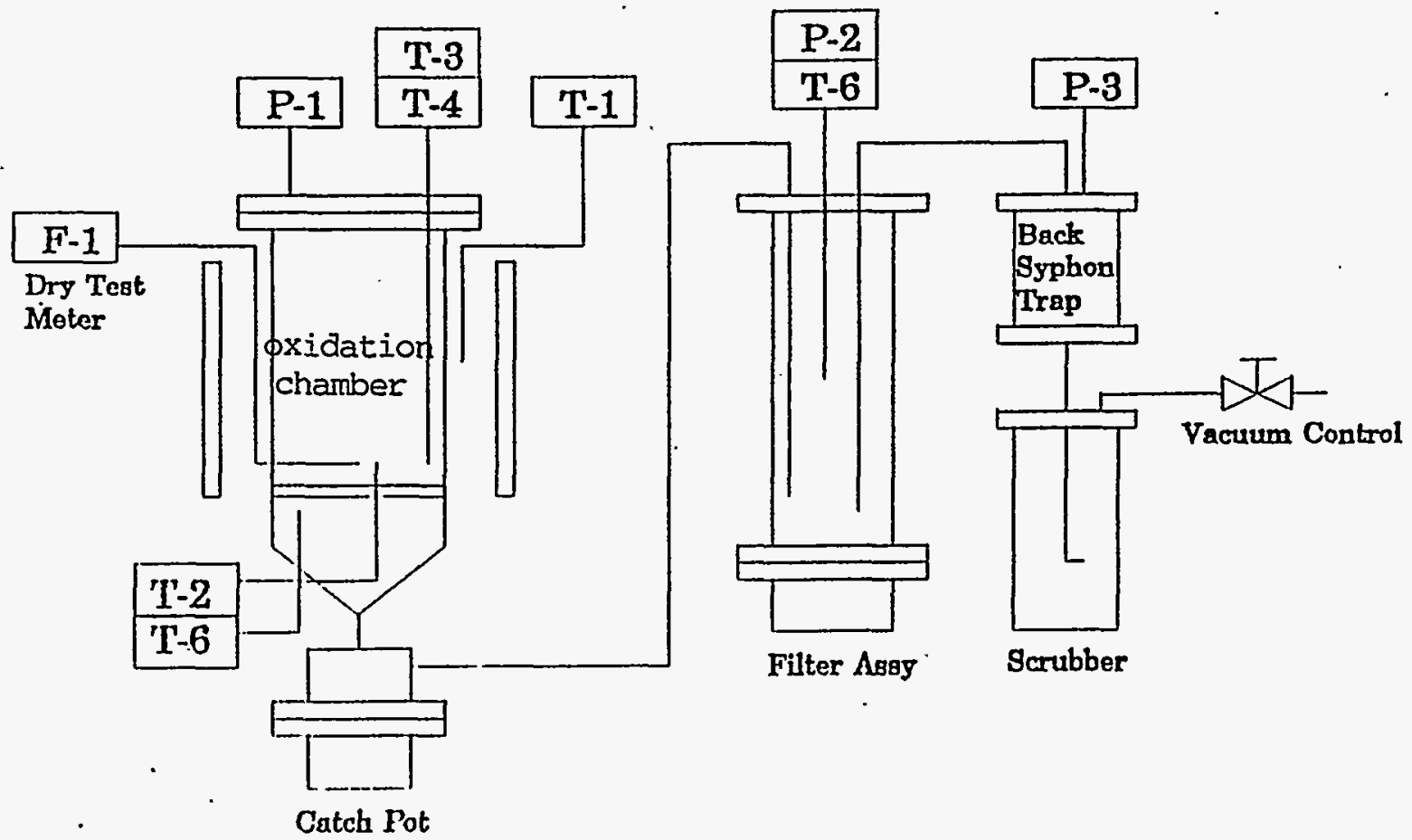

F-1 Gas Flow In

P-1 Pressure: Combustion Chamber

P-2 Pressure Differential: Filter Assembly

P-3 Pressure Differential: Scrubber Assembly

T-1 Temperature: Oxidation Chamber Skin

T-2 Temperature: Center of Rag Carton

T-3 Temperature: Above Grate

T-4 Temperature: Above Grate

T-5 Temperature: Below Grate

T-6 Temperature: Inside Filters

Figure 2.1. Instrument Points and Flow Diagram

\subsection{Filter Assembly}

The filter assembly is constructed of 4-in. Schedule 40 glass piping (see Figure 2.2). The filter assembly is connected to the oxidation chamber assembly's catch pot with 1 -in. Schedule 40 black piping. A catch pot, constructed of 4-in. Schedule 40 black piping, for collecting particulates is connected to the botton or the main filter body with a 4-in. glass-to-steel pipe flange. Two $1 / 2$ in. $x 10$ in. SS, 


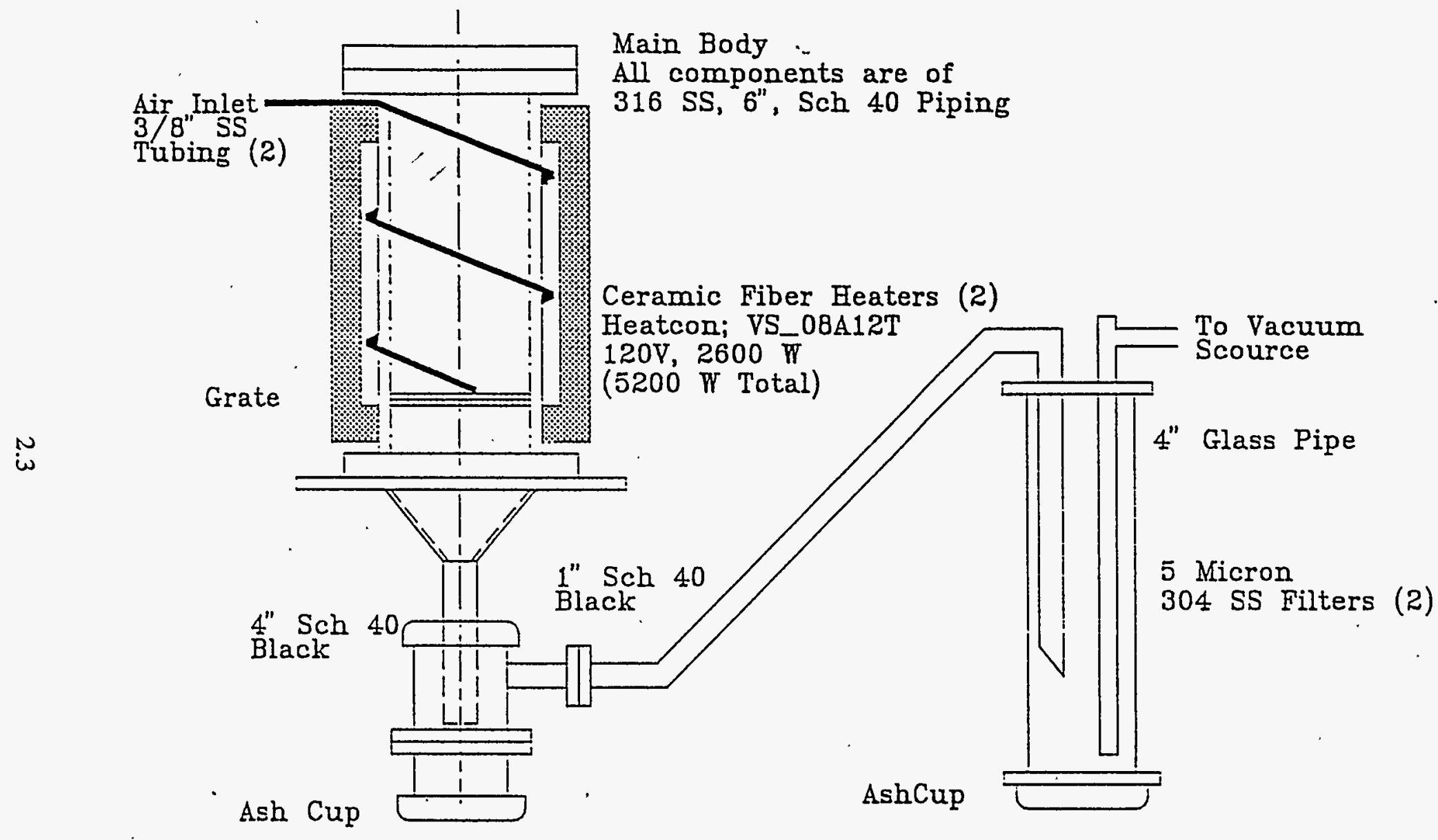

Figure 2.2. Downdraft Thermal Oxidation 
5-micron tubular filters are housed inside the main filter body. For experimental runs, each filter was wrapped with a thin layer of kaowool to prevent plugging of the filters by condensing tars and particulates.

A differential pressure gauge measures the pressure drop across the filters to monitor filter loading. A thermocouple located inside one of the two filters monitors' air temperature leaving the filter assembly. A septa port for obtaining gas samples is located above the other filter in the outlet gas stream.

\subsection{Scrubbing Assembly}

The scrubbing assembly consists of a scrubber housed in a single assembly. Cooling water feeds through the jacket of the scrubbing assembly to condense hot gases entering the assembly. Prior to each run, the scrubber was loaded with a measured amount of water. After each run, the water was removed and weighed.

A differential pressure gauge measures pressure drop across the scrubbing assembly. A thermocouple in the line exiting the scrubber monitors gas temperature entering the vacuum pump.

\subsection{Vacuum Pump}

A Model 1397 Welch mechanical vacuum pump supplies vacuum to the system. The pump is capable of a free air displacement of $500 \mathrm{~L} / \mathrm{min}$. Without any water in the scrubber assembly, the pump easily maintained a draw of $200 \mathrm{~L} / \mathrm{min}$ at the air inlet to the thermal oxidation chamber at 25 in. $\mathrm{H}_{2} \mathrm{O}$ vacuum. 


\subsection{Experimental Procedures and Results}

This section describes the eight experimental runs and the results obtained from the tests.

\subsection{Leak Rate Test}

The system was placed under 30 in. $\mathrm{H}_{2} \mathrm{O}$ of vacuum, and the leak rate was observed. A vacuum drop to 10 in. was observed in $5.8 \mathrm{sec}$. Leak rate was determined to be $3.5 \mathrm{in}$. $\mathrm{H}_{2} \mathrm{O} / \mathrm{sec}(\sim 28 \mathrm{~L} / \mathrm{m})$ at

the beginning of the test series. Another leak rate check was made after Run \#5 (see Section 3.3.5).

\subsection{CHN Analysis of Glove Box Wipers}

Two tests were made to determine the carbon, hydrogen, and nitrogen content of the rags used for this study (14 in. $\times 14$ in. $100 \%$ cotton towels). Prior to testing, the rags were dried to remove all water content. The results are summarized in Table 3.1 .

Table 3.1. CHN Analysis

\begin{tabular}{|c|c|c|c|c|}
\hline Sample Name & $\begin{array}{l}\text { C Analysis } \\
\% \text { total wt }\end{array}$ & $\begin{array}{l}\text { H Analysis } \\
\% \text { total wt }\end{array}$ & $\begin{array}{l}\mathrm{N} \text { Analysis } \\
\% \text { total wt }\end{array}$ & Average Total \% \\
\hline $100 \%$ cotton rags & 43.28 & 6.35 & 0 & \\
\hline Repeat & 42.42 & 6.28 & 0 & 42.85 \\
\hline Round Carton & 46.17 & 7.21 & 0 & \\
\hline Repeat & 46.34 & 7.18 & 0 & 46.26 \\
\hline
\end{tabular}

\subsection{Experimental Runs}

Each run was started by turning the variac on to $80 \%$, supplying 19 amps to each heater. After 8 min of heating, air flow through the system was started by pulling approximately $15 \mathrm{~L} / \mathrm{min}$ of air through the system with the vacuum pump. When the temperature inside the carton of wipers started to climb, air flow through the system was turned to the maximum the vacuum pump could achieve. When a rapid temperature increase was observed in the carton of wipers, the variac was turned off and the experiment allowed to run to completion. After $107 \mathrm{~min}$ from startup, the vacuum pump was turned off and the experiment concluded. The oxidation chamber was always allowed to cool to at least $80^{\circ} \mathrm{C}$ before the interior was opened and examined. 
Experimental results for the testing include a gravimetric analysis of the ash from each run. An offgas analysis from some of the runs was also made with a gas chromatograph. Ash was collected with a small hand-held vacuum, at the conclusion of each run, from the interior of the oxidation chamber, the grate, and the oxidation chamber's catch pot. Gas samples were taken periodically from the offgas line from the filter assembly. A carbon balance by gas analysis was attempted for some of the runs. The results are inconclusive, however, because none of the ash from the catch pots or the water from the scrubber was analyzed for carbon content. Also, gas analysis results in some cases tended to indicate that more carbon came out of the system then went in. This could be attributed to either a larger difference in carbon content between rags than results from a CHN analysis indicated, or

an inaccurate calibration standard for the gas chromatograph. Further testing is needed to ascertain the source of the discrepancies.

\subsubsection{Run \#1: Dry Rags, Loosely Packed}

A round carton and three rags were oven dried at $90^{\circ} \mathrm{C}$ for approximately $3 \mathrm{hr}$.

\begin{tabular}{lr} 
Carton wt & $\begin{array}{r}44.49 \mathrm{~g} \\
\text { Rag wt }\end{array}$ \\
Total wt & $214.03 \mathrm{~g}$ \\
\hline
\end{tabular}

The rags were loosely packed in a round carton and loaded into the oxidation chamber. A 1/4 in. $x 1 / 4$ in. SS mesh was placed between the bottom of the carton and the grate to facilitate ash recovery. The variac was turned on to $80 \%$, supplying 19 amps to each heater. The vacuum pump was not initially turned on. A worksheet summary of the experiment is given in Table 3.2. Note: for Table 3.2 and the worksheet summaries for the other runs, temperatures are in degrees $\mathrm{C}$; pressures are in inches $\mathrm{H}_{2} \mathrm{O}$. A graph of the temperature profile for Run \#1 is included in Section 3.4. [Section 3.4 also includes graphs for Runs \#2, 3, 5-8.]

After the experiment, the 6-in. blank flange at the top of the oxidation chamber assembly was removed and a small hand-held vacuum was used to collect the ash. When vacuuming was completed, the ash cup was removed to collect the ash and other noncombustibles. There was a white ash on a "glob" of dry black tar in the bottom of the ash cup.

$\begin{array}{ll}\text { Ash from grate } & 0.62 \mathrm{~g} \\ \text { Ash from cup } & 0.05 \mathrm{~g} \\ \text { Tar } & \underline{0.82 \mathrm{~g}} \\ \text { Total } & 1.49 \mathrm{~g}\end{array}$


Table 3.2. Experimental Run \#1

\begin{tabular}{|c|c|c|c|c|c|c|c|}
\hline Time & $\mathbf{T 1}$ & $\mathbf{T} 2$ & T3 & T5 & $\mathbf{P 1}$ & $\Delta \mathbf{P 2}$ & Comments \\
\hline $7: 47$ & 16.4 & 16.5 & 16.3 & 15.8 & $\overline{0}$ & 10 & Variac on @ $80 \%$ (19 amps to each heater) \\
\hline $7: 54$ & 407 & 17.1 & 70 & 63 & 0 & 10 & Air on @ $15 \mathrm{~L} / \mathrm{min}$ \\
\hline $7: 58$ & 512 & 33 & 167 & 119 & 30 & 10 & Air on@15 L/min \\
\hline $8: 02$ & 582 & 96 & 330 & 182 & 37 & 10 & Air on @ $124 \mathrm{~L} / \mathrm{min}$ \\
\hline $8: 04$ & & & & & & & Smoke observed in filter assembly \\
\hline $8: 07$ & 662 & 223 & 689 & 365 & 37 & 10 & \\
\hline 8:08 & 679 & 303 & 732 & 396 & 37 & 10 & \\
\hline $8: 10$ & 730 & 430 & 878 & 506 & 37 & 10 & \\
\hline $8: 12$ & 772 & 887 & 730 & 514 & 37 & 10 & \\
\hline $8: 13$ & 781 & 979 & 744 & 533 & 37 & 10 & \\
\hline $8: 15$ & 749 & 928 & 734 & 563 & 40 & 10 & Variac turned off \\
\hline $8: 20$ & 596 & 664 & 600 & 533 & 36 & 10 & Total air $=1900 \mathrm{~L} ;$ rate $=132 \mathrm{~L} / \mathrm{min}$ \\
\hline $8: 27$ & 447 & 339 & 439 & 442 & 32 & 10 & Total air $=2750 \mathrm{~L}$ \\
\hline $8: 33$ & 359 & 320 & 350 & 370 & 28 & 10 & Total air $=3610 \mathrm{~L}$ \\
\hline $8: 43$ & 256 & 233 & 250 & 278 & 25 & 10 & Total air $=4970$ \\
\hline $8: 58$ & 167 & 158 & 163 & 188 & 22 & 9.5 & Total air $=7000$ \\
\hline $9: 20$ & 101 & 104 & 101 & 116 & 21 & 9 & Total air $=10,050$ \\
\hline 9:55 & 62 & 67 & 62 & 68 & 20 & 8.5 & Total air $=14,900 ;$ vacuum pump off \\
\hline
\end{tabular}

Thermocouple placement for Run \#1:

$\begin{array}{ll}\text { T1 } & \text { Skin Temperature } \\ \text { T2 } & \text { Inside Container } \\ \text { T3 } & \text { Grate } \\ \text { T5 } & \text { Below Grate }\end{array}$

\subsubsection{Run \#2: Dry Rags, Tightly Packed}

A round carton and six rags were dried at $90^{\circ} \mathrm{C}$ for $2 \mathrm{hr}$. The rags were rolled together to make a tight fit in the carton. This run was essentially a repeat of the first run except for the tight packing and number of rags. This experiment was done to determine if a significant difference between test results would occur as a result of using a different packing procedure. The stainless steel wire mesh was not placed in between the grate and carton. A worksheet summary of the experiment is provided in Table 3.3. 
Table 3.3. Experimental Run \#2

\begin{tabular}{|c|c|c|c|c|c|c|c|}
\hline Time & $\mathbf{T 1}$ & $\mathbf{T} 2$ & $\mathbf{T 3}$ & T5 & $\mathbf{P 1}$ & $\Delta \mathbf{P 2}$ & Comments \\
\hline$\overline{13: 15}$ & $\overline{20.6}$ & $\overline{21.2}$ & $\overline{20.4}$ & $\overline{20.6}$ & $\overline{0}$ & $\overline{0}$ & $\overline{\text { Variac@80\% }}$ \\
\hline $13: 22$ & 413 & 21.1 & 157 & 42 & 0 & 0 & Air on @ $20 \mathrm{~L} / \mathrm{min}$ \\
\hline $13: 27$ & 542 & 27.7 & 340 & 121 & 0 & 0 & \\
\hline $13: 29$ & 578 & 74.5 & 391 & 169 & 34 & 11 & Air on @ $132 \mathrm{~L} / \mathrm{min}$ \\
\hline $13: 35$ & & & 577 & 413 & 35 & 12 & Air total $=900 \mathrm{~L} ;$ rate $=129 \mathrm{~L} / \mathrm{min}$ \\
\hline $13: 39$ & 731 & 273 & 647 & 528 & 37 & 12 & \\
\hline $13: 48$ & 822 & 601 & 783 & 670 & 43 & 12 & Air @130 L/min \\
\hline $13: 51$ & & & & & & & Variac off \\
\hline $13: 56$ & 655 & 776 & 678 & 634 & 42 & 13 & $\mathrm{~T} 6$ (air to vacuum pump) at $92: 8^{\circ} \mathrm{C}$ \\
\hline $14: 02$ & 535 & 569 & 560 & 542 & 37 & 13 & Total air $=4380 \mathrm{~L}$ \\
\hline $14: 10$ & 417 & 398 & 448 & 449 & 34 & 13 & Air @ 142 L/min \\
\hline $14: 19$ & 302 & 289 & 315 & 336 & 30 & 13 & Air @ 144 L/min \\
\hline $14: 23$ & & & & & 29 & 13 & Total air $=7400 \mathrm{~L}$ \\
\hline $14: 30$ & 218 & 213 & 224 & 246 & 27 & 13 & Air @ 145 L/min \\
\hline $14: 42$ & 157 & 162 & 163 & 181 & 25 & 12 & \\
\hline $14: 55$ & 118 & 127 & 121 & 135 & 25 & 12 & \\
\hline $14: 57$ & & & & & & & $\begin{array}{l}\text { Vacuum pump off; total air = } \\
12,490 \mathrm{~L}\end{array}$ \\
\hline
\end{tabular}

$\begin{array}{lr}\text { Carton wt } & 44.9 \mathrm{~g} \\ \text { Rag wt } & 325.2 \mathrm{~g} \\ \text { Total wt } & 370.1 \mathrm{~g}\end{array}$

$280.0 \mathrm{~g} \mathrm{H}_{2} \mathrm{O}$ added to scrubber assembly.

The same procedure as used in Run \#1 was used to collect and weigh the ash.

$\begin{array}{ll}\text { Ash from grate } & 0.53 \mathrm{~g} \\ \text { Ash from Cup } & \underline{1.02 \mathrm{~g}} \\ \text { Total } & 1.57 \mathrm{~g}\end{array}$

$329.1 \mathrm{~g} \mathrm{H}_{2} \mathrm{O}$ collected from scrubber assembly. 


\subsubsection{Run \#3: Wet Rags}

A round container and five rags were dried overnight at a temperature of $90^{\circ} \mathrm{C}$. The rags were then soaked in water and wrung out to simulate typical wet rags from storage drums. In order to minimize experimental variables, every attempt was made to duplicate Run \#2 with regard to air flows and variac timing. The filter assembly was modified to include a septa for taking gas samples of the product gas. A worksheet summary of the experiment is included as Table 3.4. A worksheet summary of the gas analysis is included as Table 3.5. Gas analysis was by a Carle gas chromatograph.

$\begin{array}{lr}\text { Carton wt } & 46.9 \mathrm{~g} \\ \text { Rag wt } & 279.4 \mathrm{~g} \\ \mathrm{H}_{2} \mathrm{O} \text { wt } & 69.9 \mathrm{~g} \\ \text { Total wt } & 403.1 \mathrm{~g}\end{array}$

$280 \mathrm{~g} \mathrm{H}_{2} \mathrm{O}$ added to scrubber assembly.

$306.5 \mathrm{~g} \mathrm{H}_{2} \mathrm{O}$ removed from scrubber assembly (26.5 g gain).

Table 3.4. Experimental Run \#3

\begin{tabular}{|c|c|c|c|c|c|c|c|}
\hline Time & $\mathbf{T 1}$ & $\mathbf{T} 2$ & T3 & T5 & P1 & $\Delta \mathbf{P 2}$ & Comments \\
\hline $9: 45$ & 20.3 & 21.7 & 18.6 & 18.4 & 0 & 0 & Variac on @ $80 \%$ \\
\hline $9: 53$ & 454 & 21.0 & 182 & 56.0 & 3 & 0 & Air on $@ 16 \mathrm{~L} / \mathrm{min}$ \\
\hline $9: 59$ & 575 & 70 & 375 & 176 & 37 & 20 & Air on @ $130 \mathrm{~L} / \mathrm{min}$ \\
\hline $10: 05$ & 643 & 89 & 558 & 602 & 34 & 20 & Air on full @ $122 \mathrm{~L} / \mathrm{min}$ \\
\hline $10: 10$ & 724 & 89 & 652 & 663 & 35 & 20 & Total air = $1570 \mathrm{~L} ;$ air @ $118 \mathrm{~L} / \mathrm{min}$ \\
\hline $10: 17$ & 823 & 150 & 826 & 690 & 40 & 16 & Total air $=2280 \mathrm{~L}$ \\
\hline $10: 20$ & 846 & 448 & 806 & 702 & 40 & 16 & Variac off; Total air $=2720 \mathrm{~L}$ \\
\hline $10: 24$ & 709 & 730 & 718 & 678 & $37^{\circ}$ & 15 & Total air = $3200 \mathrm{~L} ;$ air @ $126 \mathrm{~L} / \mathrm{min}$ \\
\hline $10: 30$ & 597 & 578 & 597 & 601 & 35 & 15 & Total air = $4000 \mathrm{~L} ;$ air @ $130 \mathrm{~L} / \mathrm{min}$ \\
\hline $10: 40$ & 401 & 373 & 403 & 428 & 31 & 15 & \\
\hline $10: 45$ & 336 & 316 & 339 & 368 & 28 & 15 & Air @ $135 \mathrm{~L} / \mathrm{min}$ \\
\hline $10: 54$ & 252 & 243 & 256 & 284 & 25 & 14 & Total air = $7050 \mathrm{~L} ;$ air @ $140 \mathrm{~L} / \mathrm{min}$ \\
\hline $11: 21$ & 135 & 140 & 137 & 154 & 22 & 14 & Total air = 10,650 L; air @ $142 \mathrm{~L} / \mathrm{min}$ \\
\hline $11: 25$ & 120 & 128 & 124 & 138 & & & Vacuum pump off; total air $=11,400 \mathrm{~L}$ \\
\hline
\end{tabular}


Table 3.5. Average Gas Analysis for Experimental Run \#3

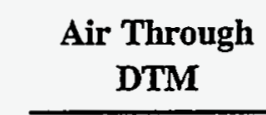

(L)

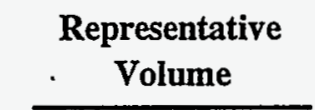

(L)

305

745

875

775

1040

1120

4540

2000
$\underline{\mathrm{CO}_{2}} \mathrm{CO}$

(L)

0.92

37.70

40.62

57.74

47.53

8.06

7.3

2.0

(L)

24.51

31.68

4.11

2.18
C

(L)

\begin{tabular}{c}
$\mathrm{CH}_{4}$ \\
\hline (L) \\
1.04 \\
2.63
\end{tabular}

0.60

.04

0.96

2.63

2.19

$\mathrm{H}_{2}$

(L)

$9400-11,400$

2000

\subsubsection{Run \#4: Simulated Loading with $\mathrm{HNO}_{3}, \mathrm{Na}_{2} \mathrm{CO}_{3}$, and $\mathrm{Fe}\left(\mathrm{NO}_{3}\right)_{3}$}

Fifty grams of $70 \% \mathrm{HNO}_{3}$ were added to $450 \mathrm{~g}$ tap water. $\mathrm{Na}_{2} \mathrm{CO}_{3}$ was added to the solution until fizzing stopped. This procedure was used to simulate neutralization procedures inside a glove box. Density of the resultant solution was $1.067 \mathrm{~g} / \mathrm{mL} ; 44.61 \mathrm{~g}$ of $\mathrm{Fe}\left(\mathrm{NO}_{3}\right)_{3} * 9 \mathrm{H}_{2} \mathrm{O}$ were then added to the solution. The iron nitrate used came from a standard laboratory sample jar and was greenish in color. This could have been due to some cross contamination or possibly a mislabel. Although the discrepancy was noted prior to the experiment, a decision to use the sample was made and the experiment continued.

A round container and five rags were dried overnight at $90^{\circ} \mathrm{C}$. The neutralized solution was dripped onto the rags and then left to sit in a covered beaker overnight. This procedure resulted in an uneven distribution of solution throughout the rags. A worksheet summary of the experiment is provided in Table 3.6. 
Table 3.6. Experimental Run \#4

\begin{tabular}{|c|c|c|c|c|c|c|c|}
\hline Time & $\mathbf{T 1}$ & $\mathbf{T} 2$ & T3 & T5 & P1 & $\Delta \mathbf{P 2}$ & Comments \\
\hline$\overline{7: 45}$ & $\overline{16.2}$ & $\overline{15.8}$ & $\overline{16.1}$ & $\overline{16.4}$ & $\overline{0}$ & $\overline{0}$ & Variac on $80 \%$ \\
\hline $7: 53$ & 437 & 15.7 & 134 & 55 & 1.5 & 0 & Air on @ $8 \mathrm{~L} / \mathrm{min}$ \\
\hline $7: 58$ & 563 & 19.8 & 304 & 155 & 2.0 & 0 & \\
\hline $8: 00$ & 591 & 60 & 422 & 211 & 37 & 16 & Air on full \\
\hline $8: 08$ & 739 & 92.6 & 765 & 545 & 33 & 30 & Total air =1140 L; air @ 110 L/min \\
\hline $8: 13$ & 812 & 92.3 & 870 & 656 & 35 & 30 & Total air =1650 L; air @ 110 L/min \\
\hline $8: 16$ & 843 & 97 & 845 & 692 & 39 & 24 & Total air = 2050 L; air @ 115 L/min \\
\hline $8: 19$ & 865 & 127 & 856 & 717 & 40 & 20 & Variac off; total air $=2370 \mathrm{~L}$ \\
\hline $8: 22$ & 757 & 415 & 791 & 705 & 39 & 20 & Total air = 2730; air @ 123 L/min \\
\hline $8: 26$ & 663 & 678 & 691 & 651 & 37 & 19 & \\
\hline $8: 31$ & 570 & 777 & 581 & 581 & 35 & 19 & Total air = $3880 \mathrm{~L} ;$ air @ $127 \mathrm{~L} / \mathrm{min}$ \\
\hline $8: 44$ & 378 & 566 & 390 & 420 & 30 & 19 & Total air = $5590 \mathrm{~L} ;$ air @ $135 \mathrm{~L} / \mathrm{min}$ \\
\hline $8: 50$ & 315 & 458 & 330 & 363 & 28 & 19 & Total air = $6412 \mathrm{~L} ;$ air @ $138 \mathrm{~L} / \mathrm{min}$ \\
\hline $9: 00$ & 243 & 304 & 254 & 287 & 26 & 19 & \\
\hline $9: 10$ & 189 & 227 & 202 & 229 & 25 & 18 & Total air = 10,580 L; air @ $142 \mathrm{~L} / \mathrm{min}$ \\
\hline $9: 20$ & 152 & 173 & 162 & 183 & 24 & 17 & \\
\hline $9: 24$ & 140 & 161 & 154 & 170 & 24 & 17 & Vacuum pump off; total air $=11,215 \mathrm{~L}$ \\
\hline
\end{tabular}

Prior to experiment, $280.5 \mathrm{~g}$ water added to the scrubber assembly.

$\begin{array}{ll}\text { Carton wt } & 44.85 \mathrm{~g} \\ \text { Dry rag wt } & 296 \mathrm{~g} \\ \text { Wet rag wt } & \frac{448.1 \mathrm{~g}}{492.95 \mathrm{~g}} \\ \text { Total wt } & 492.9\end{array}$

There was a large deposit of multicolored ash left sitting on the grate at the conclusion of this run. The volume of the ash was approximately $1 / 2$ the volume of the original cylindrical carton. The ash was red, green, brown, white, and black in color. Most of the ash resembled the fibrous shape of the rag's cotton fibers. When touched, the ash crumbled to a fine powder. Because of the unusual results from this experiment and the discrepancy in the color of the iron nitrate, this experiment was repeated with some fresh iron nitrate. A worksheet for the gas analysis of Run \#4 is shown in Table 3.7. 
Table 3.7. Average Gas Analysis of Experimental Run \#4

\begin{tabular}{|c|c|c|c|c|c|c|}
\hline Range & $\begin{array}{c}\text { Representative } \\
\text { Volume }\end{array}$ & $\mathrm{CO}_{2}$ & $\mathrm{CO}$ & $\mathrm{C}=\mathrm{C}$ & $\mathrm{CH}_{4}$ & $\mathrm{H}_{2}$ \\
\hline (L) & (L) & (L) & (L) & (L) & $(\mathrm{L})$ & (L) \\
\hline $0-226$ & 226 & 6.71 & 2.58 & & & \\
\hline $226-770$ & $544^{\circ}$ & 32.31 & 16.86 & 0.59 & 7.07 & 0.82 \\
\hline $1475-2100$ & 625 & 45.12 & & & & \\
\hline $2100-2775$ & 675 & 40.16 & & . & & \\
\hline$-3465-4375$ & 910 & 22.20 & & & & \\
\hline $4375-6345^{\circ}$ & 1970 & 23.64 & 5.71 & & & \\
\hline $6345-9035$ & 2690 & 19.37 & & & & \\
\hline $9035-11,215$ & 2180 & 5.45 & & & . & \\
\hline $770-1475$ & 705 & 54.50 & 3.95 & & & \\
\hline $2775-3465$ & 690 & 26.91 & & & & \\
\hline
\end{tabular}

\subsubsection{Run \#5: Rags Soaked in $\mathrm{Fe}\left(\mathrm{NO}_{3}\right)_{3}$ and Water}

To simulate a different method by which rags might be treated in a glove box environment, dried rags were dipped into an acidic iron nitrate solution then quickly rinsed with water for neutralization. In preparation for the experiment, five rags and a cylindrical carton were dried overnight at $90^{\circ} \mathrm{C}$; $293.0 \mathrm{~g}$ of a solution containing $89.22 \mathrm{~g}$ of $\mathrm{Fe}\left(\mathrm{NO}_{3}\right)_{3}$ in $70 \% \mathrm{HNO}_{3}$ were prepared. The dry rags were placed in the solution and allowed to sit for $5 \mathrm{~min}$. The dry rags easily absorbed the iron nitrate, nitric acid solution. Each rag was then individually rinsed in the same beaker containing $1000 \mathrm{~g}$ of tap water. Each rinse lasted $30 \mathrm{sec}$ with some agitation. The rinsed rag was wrung out over the beaker containing the rinse water. The rags were then stored overnight in a covered beaker. The rinse water was analyzed and found to contain 9.074 of $\mathrm{Fe}$. The worksheet summary of the experiment is given in Table 3.8. 
Table 3.8. Experimental Run \#5

\begin{tabular}{|c|c|c|c|c|c|c|c|}
\hline Time & $\mathbf{T 1}$ & $\mathbf{T} 2$ & T3 & T5 & $\mathbf{P 1}$ & $\Delta \mathrm{P} 2$ & Comments \\
\hline $7: 45$ & 20.7 & 17.7 & 18.9 & 19.0 & 0 & 0 & Variac on @ 80\% \\
\hline $7: 48$ & 293 & 18 & 30 & & 2 & 1 & Air on $@ 15 \mathrm{~L} / \mathrm{min}$ \\
\hline $7: 52$ & 437 & 18 & 98 & 58 & 3 & 1 & \\
\hline $7: 59$ & 576 & 18 & 259 & 191 & 37 & & Air on full @ $170 \mathrm{~L} / \mathrm{min}$ \\
\hline $8: 01$ & 589 & 34 & 286 & 223 & 33 & 16 & Air@127 L/min \\
\hline $8: 06$ & 619 & 97 & 322 & 320 & 32 & 18 & Total air $=1100 \mathrm{~L}$ \\
\hline $8: 09$ & 633 & 97 & 344 & 354 & 30 & 25 & $\begin{array}{l}\text { Total air = } 1400 \mathrm{~L} ; \text { air @ } 120 \mathrm{~L} / \mathrm{min} \text {; } \\
\text { condensate coming into filter assembly }\end{array}$ \\
\hline $8: 13$ & 664 & 95 & 447 & 417 & 29 & 30 & Total air = $1840 \mathrm{~L} ;$ air @ $107 \mathrm{~L} / \mathrm{min}$ \\
\hline $8: 16$ & 692 & 90 & 556 & 480 & 28 & 30 & Total air = $2160 \mathrm{~L} ;$ air @ $105 \mathrm{~L} / \mathrm{min}$ \\
\hline $8: 19$ & 726 & 94 & 686 & 553 & 30 & 30 & Total air = $2475 \mathrm{~L} ;$ air @ 107 L/min \\
\hline $8: 22$ & 764 & 93 & 741 & 608 & 32 & 30 & \\
\hline $8: 26$ & 812 & 91 & 778 & 663 & 35 & 30 & Total air = $3235 \mathrm{~L}$; air @ $110 \mathrm{~L} / \mathrm{min}$ \\
\hline $8: 31$ & 857 & 90 & 821 & 716 & 38 & 28 & Total air = $3780 \mathrm{~L}$; air @ $112 \mathrm{~L} / \mathrm{min}$ \\
\hline $8: 35$ & 880 & 89 & 831 & 741 & 40 & 25 & Total air = $4235 \mathrm{~L}$; air @ $116 \mathrm{~L} / \mathrm{min}$ \\
\hline $8: 38$ & 889 & 90 & 821 & 716 & 38 & 28 & Total air =4580 L; air @ $116 \mathrm{~L} / \mathrm{min}$ \\
\hline $8: 41$ & 896 & 221 & 834 & 761 & 40 & 23 & Variac off; air @118 L/min \\
\hline $8: 44$ & 794 & 431 & 793 & 744 & 40 & 23 & \\
\hline $8: 48$ & 691 & 572 & 709 & 683 & 38 & 23 & Total air = $5770 \mathrm{~L} ;$ air @ $124 \mathrm{~L} / \mathrm{min}$ \\
\hline $8: 52$ & 612 & 786 & 630 & 621 & 35 & 23 & Total air = $6270 \mathrm{~L} ;$ air @ $124 \mathrm{~L} / \mathrm{min}$ \\
\hline 8.56 & 541 & 759 & 554 & 563 & 33 & 24 & Total air = $6770 \mathrm{~L} ;$ air @ $127 \mathrm{~L} / \mathrm{min}$ \\
\hline 9:04 & 428 & 493 & 469 & 467 & 31 & 24 & Total air $=7900 \mathrm{~L}$ \\
\hline $9: 10$ & 369 & 357 & 375 & 410 & 29 & 24 & Total air=8650 L; air @ 131 L/min \\
\hline $9: 22$ & 257 & 252 & 264 & 297 & 25 & 20 & Total air = 10,260 L; air @ $135 \mathrm{~L} / \mathrm{min}$ \\
\hline $9: 40$ & 166 & 172 & 175 & 195 & 23 & 18 & Air off; total air $=12,700 \mathrm{~L}$ \\
\hline
\end{tabular}

$\begin{array}{ll}\text { Carton wt } & 47.3 \mathrm{~g} \\ \text { Rag wt } & 293.0 \mathrm{~g} \\ \text { mquid wt } & 458.1 \mathrm{~g} \\ \text { Total wt } & 798.4 \mathrm{~g}\end{array}$


$280 \mathrm{~g}$ water added to the scrubber assembly.

$\begin{array}{ll}\text { Ash from top of grate } & 2.29 \mathrm{~g} \\ \text { Ash from ash cup } & 1.47 \mathrm{~g} \\ \text { Total ash } & 3.67 \mathrm{~g}\end{array}$

$486.0 \mathrm{~g}$ water removed from scrubber assembly (206.0 g gain).

The ash removed from the grate and the oxidation chamber ash cup was mostly reddish brown in color. White ash appeared as small chunks throughout the ash mixture. Approximately $0.4 \mathrm{~g}$ of fine red ash was also collected off of the chamber wall. The fine red ash that coated the wall also coated the inside of filter assembly and the kaowool covering the filters.

A worksheet outlining the gas analysis from Run \#5 is included as Table 3.9.

Table 3.9. Average Gas Analysis of Experimental Run \#5

\begin{tabular}{|c|c|c|c|c|}
\hline Range & $\begin{array}{c}\text { Representative } \\
\text { Volume }\end{array}$ & $\mathrm{CO}_{2}$ & $\mathrm{CO}$ & $\mathrm{C}=\mathrm{C}$ \\
\hline (L) & (L) & (L) & (L) & $\cdot \quad(\mathrm{L})$ \\
\hline $0-590$ & 590 & 1.30 & & \\
\hline $590-1195$ & 605 & 2.06 & & \\
\hline $1195-1750$ & 555 & 9.10 & 4.05 & . \\
\hline $1750-2260$ & 510 & 18.82 & 8.72 & 0.20 \\
\hline $2260-2780$ & 520 & 33.12 & 10.40 & \\
\hline $2780-3280$ & 500 & 32.70 & 2.90 & " \\
\hline $3280-3875$ & 595 & 39.03 & & \\
\hline $3875-4615$ & 740 & 38.48 & & \\
\hline $4615-5610$ & 995 & 33.23 & & \\
\hline $5610-6925$ & 1315 & 29.85 & & \\
\hline $6925-8455$ & 1570 & 25.55 & & \\
\hline $8455-10,305$ & 1850 & 7.77 & & \\
\hline $10,305-12,700$ & 2395 & 7.90 & & \\
\hline
\end{tabular}

Another check of the leak rate was made at the completion of Run \#5 to compare with results from the leak rate test performed prior to Run \#1. A blind flange was placed on the oxidation chamber side of the 1 -in. line leading from the chamber assembly to the filter assembly. A vacuum pump and 
rotameter were connected to one of the two 3/8-in. SS air inlet lines, and the other line was connected to a manometer. Vacuum was applied to the chamber assembly; a control valve to the vacuum pump was shut; and the leak rate determined by air flow through the rotameter. At room temperature and 29.5 in. $\mathrm{H}_{2} \mathrm{O}$ of vacuum, the leak rate was $9.44 \mathrm{~L} / \mathrm{min}$. Further testing at different temperatures gave the following results:

\begin{tabular}{|c|c|c|}
\hline $\begin{array}{l}\text { Oxidation Chamber Outer } \\
\text { Skin Temperature in deg C }\end{array}$ & $\begin{array}{l}\text { Vacuum in } \\
\text { inches } \mathrm{H}_{2} \mathrm{O}\end{array}$ & $\begin{array}{l}\text { Leak rate } \\
\text { in } L / m i n\end{array}$ \\
\hline 588 & 35 & 7.8 \\
\hline 659 & 32.5 & 6.8 \\
\hline 701 & 30 & 6.1 \\
\hline 752 & 30 & 5.7 \\
\hline 809 & 30 & 5.2 \\
\hline 836 & 30 & 4.9 \\
\hline
\end{tabular}

After cooling, the two heaters were removed, and the air inlet tubing examined. A small hole had developed in one of the lines at a point where the line was welded to the skin of the oxidation chamber. An attempt to repair the leak was unsuccessful. After the repair attempt, the leak rate was established once again at room temperature. At 29 in. $\mathrm{H}_{2} \mathrm{O}$ of vacuum, the leak rate was $8.26 \mathrm{~L} / \mathrm{min}$.

\subsubsection{Run \#6: Dry Rags, Catalyst Placed in the 1-in. Line from the Oxidation Chamber Assembly to the Filter Assembly}

A catalyst disk, 2 in. in diameter and 1,1/2 in. long, was used for the test. The catalyst was $0.3 \%$ platinum on a gamma alumina substrate coated on Dupont Torvex ceramic honeycomb and obtained from Strem Chemicals, Inc. The disk was placed in a 2-in. SS pipe, 3 in. long, that had been drilled and tapped for a thermocouple. A thermocouple was placed inside one of the honeycombs of the catalyst disk. The 2-in. SS pipe was placed in between the two flanges connecting the 1-in. offgas line from the oxidation chamber assembly to the filter assembly. A propane torch was used to preheat the catalyst to operating temperature before the beginning of the experiment. The kaowool around the SS filters was replaced prior to this experimental run.

When the blank flange was being removed from the 1-in. offgas line from the oxidation chamber assembly's catch pot, the line was found to be partially clogged with ash and condensed tars on the filter side of the flanged connection. The line was cleaned out and a catalyst placed between the two 1in. flanges in an attempt to achieve a more complete conversion of the offgas to $\mathrm{CO}_{2}$.

Six dry rags $(268.74 \mathrm{~g})$ were placed in a cylindrical carton $(44.73 \mathrm{~g})$ for a total loaded weight of $313.47 \mathrm{~g} ; 280 \mathrm{~g}$ of water were aduea to the scrubber assembly. A worksheet for Run \#6 is given in Table 3.10 . 
Table 3.10. Experimental Run \#6

\begin{tabular}{|c|c|c|c|c|c|c|c|}
\hline Time & $\mathbf{T 1}$ & $\mathbf{T 2}$ & T3 & $\mathrm{T} 4$ & T5 & $\mathbf{P 1}$ & Comments \\
\hline$\overline{8: 46}$ & $\overline{18.7}$ & $\overline{18.6}$ & $\overline{18.6}$ & $\overline{18.7}$ & $\overline{40}$ & $\overline{0}$ & Variac on @ $80 \%$ \\
\hline $8: 54$ & 412 & 19 & 201 & 72 & 57 & 2 & Air on@16 L/min \\
\hline $8: 57$ & & & & & & & Air on @ $47 \mathrm{~L} / \mathrm{min}$ \\
\hline 9:00 & 539 & 71 & 390 & 218 & 105 & 32 & \\
\hline 9:04 & 617 & 99 & 510 & 344 & 146 & 38 & Total air = $580 \mathrm{~L}$; air @ $147 \mathrm{~L} / \mathrm{min}$ \\
\hline $9: 10$ & 702 & 141 & 621 & 513 & 305 & 40 & Total air = $1500 \mathrm{~L} ;$ air @ $172 \mathrm{~L} / \mathrm{min}$ \\
\hline $9: 14$ & 746 & 391 & 674 & 619 & 315 & 40 & Total air = $2200 \mathrm{~L}$; air @ $176 \mathrm{~L} / \mathrm{min}$ \\
\hline $9: 18$ & 755 & 807 & 683 & 604 & 319 & 40 & $\begin{array}{l}\text { Total air = } 2900 \mathrm{~L} ; \text { air @ } 178 \mathrm{~L} / \mathrm{min} \text {; variac } \\
\text { off }\end{array}$ \\
\hline $9: 24$ & 573 & 616 & 611 & 548 & 302 & 40 & Total air $=4000 \mathrm{~L}$ \\
\hline $9: 30$ & $431^{\circ}$ & 389 & 423 & 421 & 263 & 40 & Total air = 5130 L; air @ 193 L/min \\
\hline $9: 36$ & 329 & 297 . & 323 & 330 & 229 & 40 & Total air = $6300 \mathrm{~L}$; air @ 197 L/min \\
\hline $9: 43$ & 248 & 226 & 242 & 252 & 202 & 40 & Air flow reduced from $204 \mathrm{~L} / \mathrm{min}$ to $120 \mathrm{~L} / \mathrm{min}$ \\
\hline $9: 48$ & 211 & 200 & 215 & 224 & 185 & & Catalyst torch turned off \\
\hline $9: 56$ & 174 & 170 & 179 & 188 & 156 & & Air turned off; total air $=9640 \mathrm{~L}$ \\
\hline
\end{tabular}

The catalyst bed never achieved operating temperature $\left(350^{\circ} \mathrm{C}\right.$ to $\left.400^{\circ} \mathrm{C}\right)$ during the entire run. There is too much heat transfer from the offgases to the ash cup to facilitate placement of a catalyst in the offgas line from the ash cup.

Thermocouple placement for Run \#6:

T1 Oxidation chamber skin

T2 Inside cylindrical carton

T3 Above grate

T4 Below grate

T5 Inside catalyst

$0.20 \mathrm{~g}$ ash removed from the top of the grate; $0.65 \mathrm{~g}$ black char scraped from the ash cup. Total ash removed $=0.85 \mathrm{~g}$.

292.3 g water removed from the scrubber assembly; however, an undetermined amount of water had leaked out through tis lower ball valve during the night. 


\subsubsection{Run \#7: Dry Rags, Catalyst Placed in Bottom of Conical Reducer}

The catalyst disk from the previous run was removed from the 2 -in. SS pipe that was placed in the 1-in. offgas line. The disk was then placed below the grate in the oxidation chamber assembly at the bottom of the conical reducer. A catch pot was placed above the catalyst in order to keep tars from falling into and fouling the catalyst. A thermocouple was placed inside the catalyst to monitor catalyst temperature. The SS filters were replaced with two new filters.

Six dried rags $(356.13 \mathrm{~g}$ ) were placed in a dry cylindrical carton $(44.27 \mathrm{~g})$ for a total loaded weight of $400.40 \mathrm{~g}$. A worksheet of Run \#7 is included here as Table 3.11. A worksheet of the offgas analysis is included as Table 3.12 .

Table 3.11. Experimental Run \#7

\begin{tabular}{|c|c|c|c|c|c|c|}
\hline Time & T1 & T2 & T3 & T5 & P1 & Comments \\
\hline $13: 30$ & & & & & & Torch turned on to preheat catalyst in cone \\
\hline 13:45 & 32.8 & 26.2 & 40.7 & 103 & & Variac on @ $80 \%$ \\
\hline $13: 47$ & 138 & 26 & 47 & 105 & 2 & Vacuum pump on @ $11 \mathrm{~L} / \mathrm{min}$ \\
\hline 13:50 & 319 & 27 & 112 & 123 & 2 & \\
\hline 13:54 & 430 & 27 & 228 & 134 & 2 & \\
\hline 13:58 & 517 & 29 & 336 & 167 & 2 & Air @ $12 \mathrm{~L} / \mathrm{min}$ \\
\hline 13:59 & 536 & 31 & 359 & 189 & 34 & Air on full; catalyst temperature rising rapidly \\
\hline 14:01 & 582 & 77 & 432 & 288 & 32 & Air @ $122 \mathrm{~L} / \mathrm{min}$; catalyst space red hot \\
\hline 14:04 & 630 & 95 & 530 & 333 & 32 & Air total = $750 \mathrm{~L}$; air @ $122 \mathrm{~L} / \mathrm{min}$ \\
\hline 14:08 & 690 & 99 & 605 & 388 & 33 & Air total =1230 L; air @ $118 \mathrm{~L} / \mathrm{min}$ \\
\hline 14:11 & 726 & 106 & 650 & 422 & 35 & Air total = $1590 \mathrm{~L}$; air @ $120 \mathrm{~L} / \mathrm{min}$ \\
\hline $14: 14$ & 755 & 144 & 681 & 454 & 37 & Air total =1960 L; air @ $124 \mathrm{~L} / \mathrm{min}$ \\
\hline 14:18 & 802 & 249 & 754 & 473 & 39 & Air total = $2450 \mathrm{~L}$; air @ $124 \mathrm{~L} / \mathrm{min}$ \\
\hline $14: 26$ & 713 & 730 & 716 & 504 & 38 & Air total = $3450 \mathrm{~L}$; air @ $128 \mathrm{~L} / \mathrm{min}$ \\
\hline $14: 30$ & 628 & 751 & 639 & 485 & 36 & Air total = $3960 \mathrm{~L} ;$ air $@ 130 \mathrm{~L} / \mathrm{min}$ \\
\hline $14: 36$ & 526 & 753 & 540 & 449 & 33 & Air total $=4750 \mathrm{~L} ;$ air @ $133 \mathrm{~L} / \mathrm{min}$ \\
\hline $14: 46$ & 402 & 723 & 419 & 383 & 29 & Air total = $6080 \mathrm{~L}$; air @ $135 \mathrm{~L} / \mathrm{min}$ \\
\hline $14: 54$ & 331 & 631 & 342 & 335 & 27 & Air total = $7170 \mathrm{~L} ;$ air $@ 137 \mathrm{~L} / \mathrm{min}$ \\
\hline 15:02 & 270 & 285 & 280 & 296 & 25 & Air total = $8270 \mathrm{~L}$; air @ $138 \mathrm{~L} / \mathrm{min}$ \\
\hline $15: 35$ & & 155 & 142 & 169 & 22 & Air total $=12,800 \mathrm{~L}$; vacuum pump off \\
\hline
\end{tabular}


Table 3.12. Average Gas Analysis for Experimental Run \#7

\begin{tabular}{|c|c|c|c|}
\hline Range & $\begin{array}{c}\text { Representative } \\
\text { Volume }\end{array}$ & $\mathrm{CO}_{2}$ & $\mathrm{CO}$ \\
\hline (L) & (L) & (L) & (L) \\
\hline $0-915$ & 915 & 112.4 & 16.93 \\
\hline $915-1330$ & 415 & 37.4 & 4.23 \\
\hline $1330-1770$ & 440 & 33.4 & 3.08 \\
\hline $1770-2225$ & 455 & 30.2 & 2.55 \\
\hline $2225-2705$ & 480 & 27.8 & \\
\hline $2705-3230$ & 525 & 22.6 & . \\
\hline $3230-3800$ & 570 & 21.4 & \\
\hline $3800-4390$ & 590 & 17.3 & \\
\hline $4390-5030$ & 390 & 16.4 & \\
\hline $5030-6205$ & 1175 & 21.4 & \\
\hline $6205-7815$ & 1610 & 15.9 & \\
\hline $7815-12,800$ & 4985 & 25.9 & \\
\hline
\end{tabular}

Thermocouple placement for Run \#7:

T1 Oxidation chamber skin

T2 Inside cylindrical carton

T3 Grate

T5 Catalyst

The catalyst section only remained red hot for approximately 2 min. No smoke was ever observed in the filter assembly; however, the kaowool did become slightly discolored. The discoloration could have come from residue from the last run left in the ash cup or in the 1-in. offgas line.

\begin{tabular}{ll} 
Ash from on grate & $1.20 \mathrm{~g}$ \\
$\begin{array}{l}\text { Ash from reactor walls and } \\
\text { baffle located above catalyst }\end{array}$ & $0.45 \mathrm{~g}$ \\
$\begin{array}{l}\text { Ash from ash cup } \\
\text { Total ash }\end{array}$ & $\underline{0.00 \mathrm{~g}}$ \\
\hline
\end{tabular}

\subsubsection{Run \#8: Catalyst, Rags Soaked in $\mathrm{Fe}\left(\mathrm{NO}_{3}\right)_{3}$ and Rinsed in Water}

This run was done to simulate Runs 4 and 5 with a catalyst in the offgas. Five rags were prepared by dipping each one into $106.9 \mathrm{~g}$ of a neutralized solution containing $44.65 \mathrm{~g}$ of $\mathrm{Fe}\left(\mathrm{NO}_{3}\right)_{3} * 9 \mathrm{H}_{2} \mathrm{O}$. The neutralized solution was prepared by adding $50 \mathrm{~g}$ of $70 \% \mathrm{HNO}_{3}$ to $450 \mathrm{~g}$ 
of tap water. $\mathrm{Na}_{2} \mathrm{CO}_{3}$ was added to the solution until fizzing stopped. After being dipped into the solution, each rag was allowed to sit for $15 \mathrm{~min}$ and then rinsed in $1.0 \mathrm{~L}$ of tap water. After rinsing, the rags were air dried for $2 \mathrm{hr}$ then left sitting in a covered beaker overnight; $868.0 \mathrm{~g}$ of rinse solution were later analyzed and contained approximately $5.0 \mathrm{~g}$ of Fe.

$\begin{array}{ll}\text { Cylindrical carton } & 44.3 \mathrm{~g} \\ \text { Damp Rags } & \frac{458.8 \mathrm{~g}}{503.1 \mathrm{~g}} \\ \text { Total } & \end{array}$

A torch was once again used to preheat the catalyst area prior to the experimental run. The scrubber assembly had $280.0 \mathrm{~g}$ of water added to it.

A worksheet summary for Run 8 is given in Table 3.13. A worksheet for the gas analysis is given in Table 3.14 .

Table 3.13. Experimental Run \#8

\begin{tabular}{|c|c|c|c|c|c|c|c|}
\hline Time & $\mathbf{T 1}$ & $\mathrm{T} 2$ & $\mathbf{T 3}$ & T5 & P1 & $\Delta \mathbf{P 2}$ & Comments \\
\hline$\overline{9: 44}$ & $\overline{26}$ & $\overline{19}$ & $\overline{32}$ & $\overline{106}$ & & & $\overline{\text { Variac on @ } 80 \%}$ \\
\hline $9: 46$ & 158 & 19 & 43 & 96 & 1 & 0 & Air on $@ 13 \mathrm{~L} / \mathrm{min}$ \\
\hline $9: 54$ & 458 & 20 & 254 & 142 & 2 & 0 & \\
\hline $9: 58$ & 535 & 32 & 355 & 161 & 35 & 8 & Air on full \\
\hline $10: 00$ & 558 & 68 & 403 & 222 & 30 & 10 & Total air = $390 \mathrm{~L} ;$ air @ $130 \mathrm{~L} / \mathrm{min}$ \\
\hline $10: 02$ & 589 & 81 & 454 & 566 & 30 & 10 & Total air = $640 \mathrm{~L} ;$ air @ $120 \mathrm{~L} / \mathrm{min}$ \\
\hline $10: 05$ & 630 & 85 & 537 & 323 & 30 & 10 & Total air = $1000 \mathrm{~L}$, air @ $120 \mathrm{~L} / \mathrm{min}$ \\
\hline $10: 08$ & 674 & 90 & 584 & 379 & 30 & 12 & Total air = 1370 L; air @ 120 L/min \\
\hline $10: 12$ & 722 & 88 & 656 & 417 & 33 & 12 & Total air = $1840 \mathrm{~L}$; air @ $117 \mathrm{~L} / \mathrm{min}$ \\
\hline $10: 18$ & 789 & 193 & 747 & 472 & 36 & 12 & Total air = 2550 L; air @ 117 L/min \\
\hline $10: 22$ & 822 & 489 & 773 & 507 & 38 & 15 & Total air = $3025 \mathrm{~L}$; air @ 120 L/min \\
\hline $10: 26$ & 837 & 639 & 782 & 531 & 40 & 12 & Total air = $3525 \mathrm{~L}$; air @ $122 \mathrm{~L} / \mathrm{min}$ \\
\hline $10: 30$ & 843 & 791 & 780 & 550 & 40 & 16 & Total air = $4025 \mathrm{~L}$; air @ $126 \mathrm{~L} / \mathrm{min}$ \\
\hline $10: 35$ & 840 & 797 & 774 & 560 & & & Variac off \\
\hline $10: 38$ & 738 & 726 & 729 & 550 & 38 & 12 & Total air = 5035 L; air @ $130 \mathrm{~L} / \mathrm{min}$ \\
\hline $10: 42$ & 623 & 597 & 620 & 513 & 36 & 12 & Total air $=5570 \mathrm{~L}$; torch off catalyst area \\
\hline $10: 45$ & 553 & 535 & 556 & 483 & 33 & 11 & Total air = 5950 L; air @ $132 \mathrm{~L} / \mathrm{min}$ \\
\hline $10: 55$ & 395 & 395 & 403 & 392 & 29 & 11 & Total air = $7300 \mathrm{~L}$; air @ $135 \mathrm{~L} / \mathrm{min}$ \\
\hline 11:05 & 295 & 305 & 304 & 325 & 25 & 13 & Total air = $8660 \mathrm{~L}$; air @ $138 \mathrm{~L} / \mathrm{min}$ \\
\hline 11:06 & & & & & & & Sharp crack (ping) heard. Weld cracked on air inlet line. \\
\hline $11: 15$ & 224 & 239 & 231 & 256 & 24 & 11 & Total air = 10,050 L; air @ $138 \mathrm{~L} / \mathrm{min}$ \\
\hline $11: 27$ & & & & & & & EOR; total air $=11,730 \mathrm{~L}$ \\
\hline
\end{tabular}


Water removed from scrubber assembly $392.2 \mathrm{~g}$

Ash removed from top of grate

$0.85 \mathrm{~g}$

Ash vacuumed out of reactor

$1.80 \mathrm{~g}$

Ash removed from reactor ash cup

$\underline{0.20 \mathrm{~g}}$

Total ash removed from Run \#8

$2.85 \mathrm{~g}$

Table 3.14. Average Gas Analysis of Experimental Run \#8

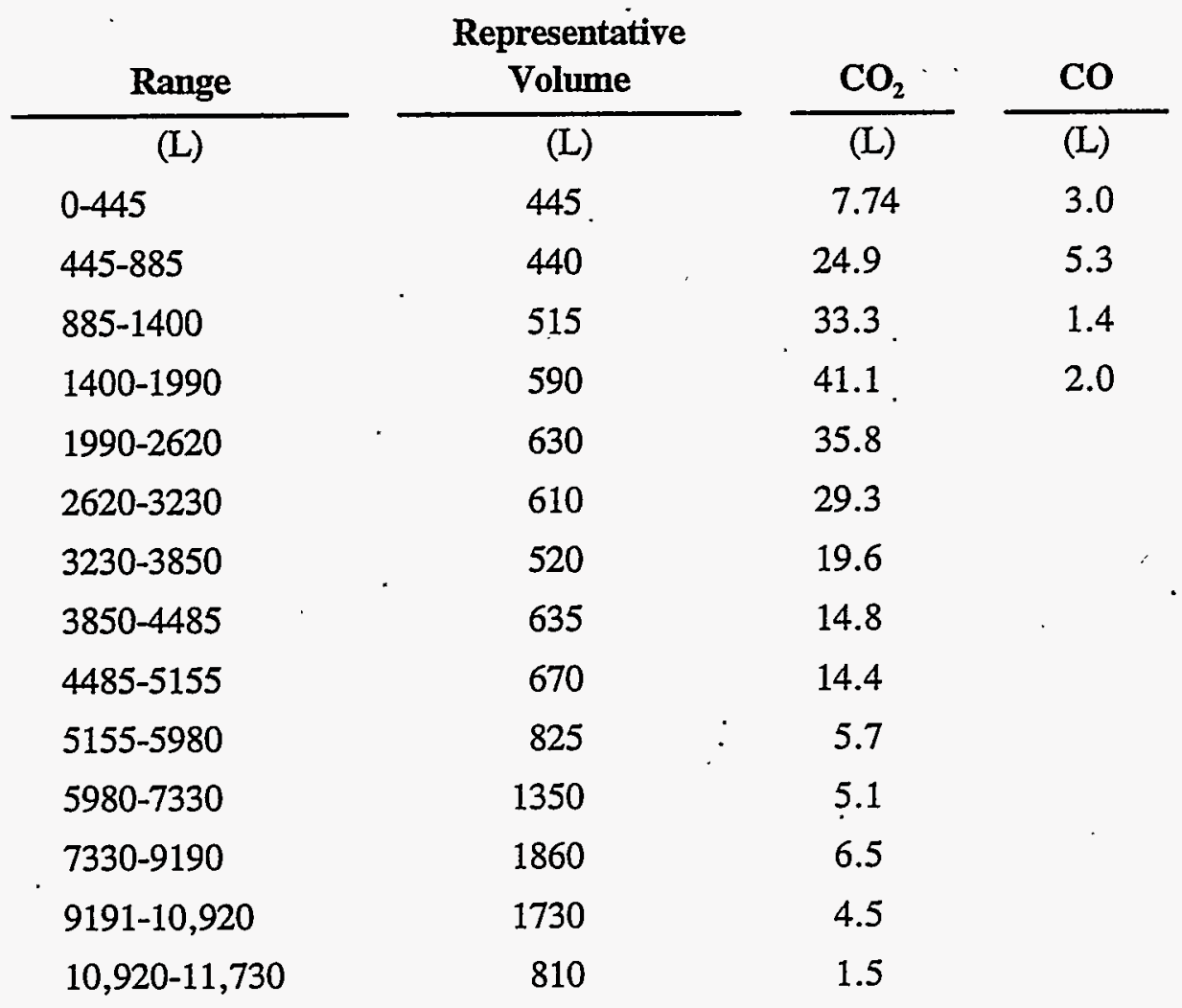

\subsection{Tabulated Test Results}

The results from.the eight experimental runs were tabulated and are shown in Table 3.15. Graphs of temperature profiles for Runs 1-3 and 5-8 are also included in this Section. 
Table 3.15. Tabulated Results of Experimental Runs \#1 Through 8

\begin{tabular}{|c|c|c|c|c|c|c|}
\hline Run \# & $\begin{array}{l}\text { Physical } \\
\text { Condition }\end{array}$ & $\begin{array}{l}\text { Chemical } \\
\text { Preparation }\end{array}$ & $\begin{array}{l}\text { Loaded } \\
\text { Wt (g) }\end{array}$ & $\begin{array}{l}\text { Ash Wt } \\
\text { (g) }\end{array}$ & $\begin{array}{c}\text { Wt } \\
\text { Reduction }\end{array}$ & $\begin{array}{l}\text { Scrubber } \\
\text { Loading (g) }\end{array}$ \\
\hline 1 & Dry, loose pack & None & 214.52 & 1.49 & $144: 1$ & \\
\hline 2 & Dry, tight pack & None & 370.1 & 1.55 & $239: 1$ & 49.1 \\
\hline 3 & Wet, tight pack & $76.8 \mathrm{~g} \mathrm{H}_{2} \mathrm{O}$ & 403.1 & 1.09 & $370: 1$ & 26.5 \\
\hline 4 & $\begin{array}{l}\text { Wet, soaked in } \\
\text { neutralized } \\
\text { solution, tight pack }\end{array}$ & $\begin{array}{l}152.1 \mathrm{~g} \\
59.3 \mathrm{wt} \% \mathrm{H}_{2} \mathrm{O} \\
6.6 \mathrm{wt} \% 70 \% \mathrm{HNO}_{3} \\
4.5 \mathrm{wt} \% \mathrm{Na}_{2} \mathrm{CO}_{3} \\
29.5 \mathrm{wt} \% \mathrm{Fe}\left(\mathrm{NO}_{3}\right)_{3}\end{array}$ & 448.1 & not determined & & \\
\hline 5 & $\begin{array}{l}\text { Wet, } \\
\text { soaked in acid, } \\
\text { rinsed in water }\end{array}$ & $\begin{array}{l}458.1 \mathrm{~g} \\
89.22 \mathrm{~g} \mathrm{Fe}\left(\mathrm{NO}_{3}\right)_{3} \\
\text { dissolved in } 10 \% \\
\mathrm{HNO}_{3} \text { to makẻ } 200 \mathrm{~g} \\
\text { of acid solution }\end{array}$ & 798.4 & 4.16 & 192:1 & 205 \\
\hline 6 & $\begin{array}{l}\text { Dry, } \\
\text { tight pack }\end{array}$ & None & 313.47 & 0.85 & $369: 1$ & 12.3 \\
\hline 7 & Dry, tight pack & None & 400.40 & 1.65 & $243: 1$ & \\
\hline 8 & $\begin{array}{l}\text { Wet, } \\
\text { soaked in } \\
\text { neutralized } \\
\text { solution, rinsed } \\
\text { in water }\end{array}$ & $\begin{array}{l}227.46 \mathrm{~g} \\
59.3 \mathrm{wt} \% \mathrm{H}_{2} \mathrm{O} \\
6.6 \mathrm{wt} \% 70 \% \mathrm{HNO}_{3} \\
4.5 \mathrm{wt} \% \mathrm{Na}_{2} \mathrm{CO}_{3} \\
29.5 \mathrm{wt} \% \mathrm{Fe}\left(\mathrm{NO}_{3}\right)_{3}\end{array}$ & 503.1 & 2.85 & $177: 1$ & 49.2 \\
\hline
\end{tabular}



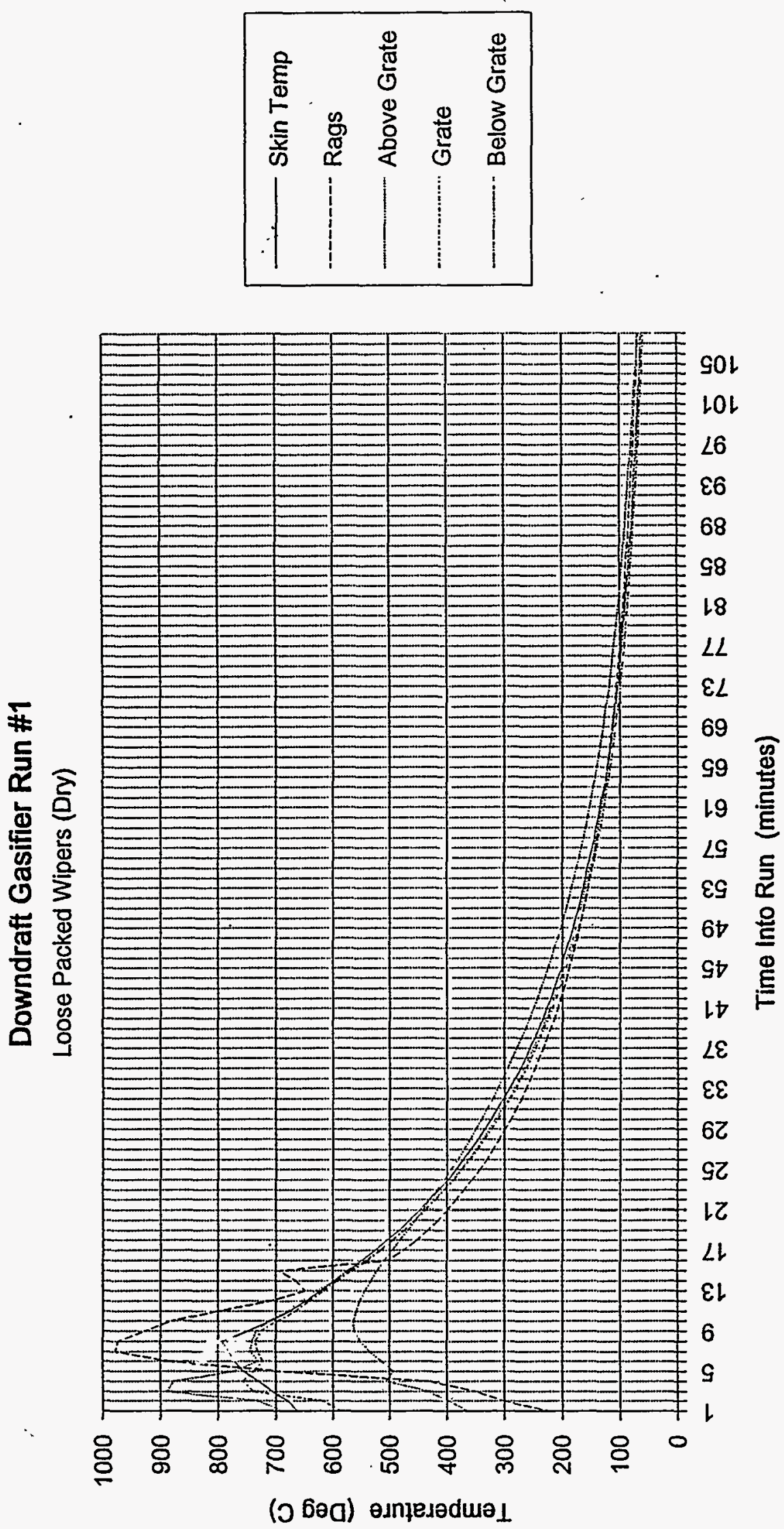


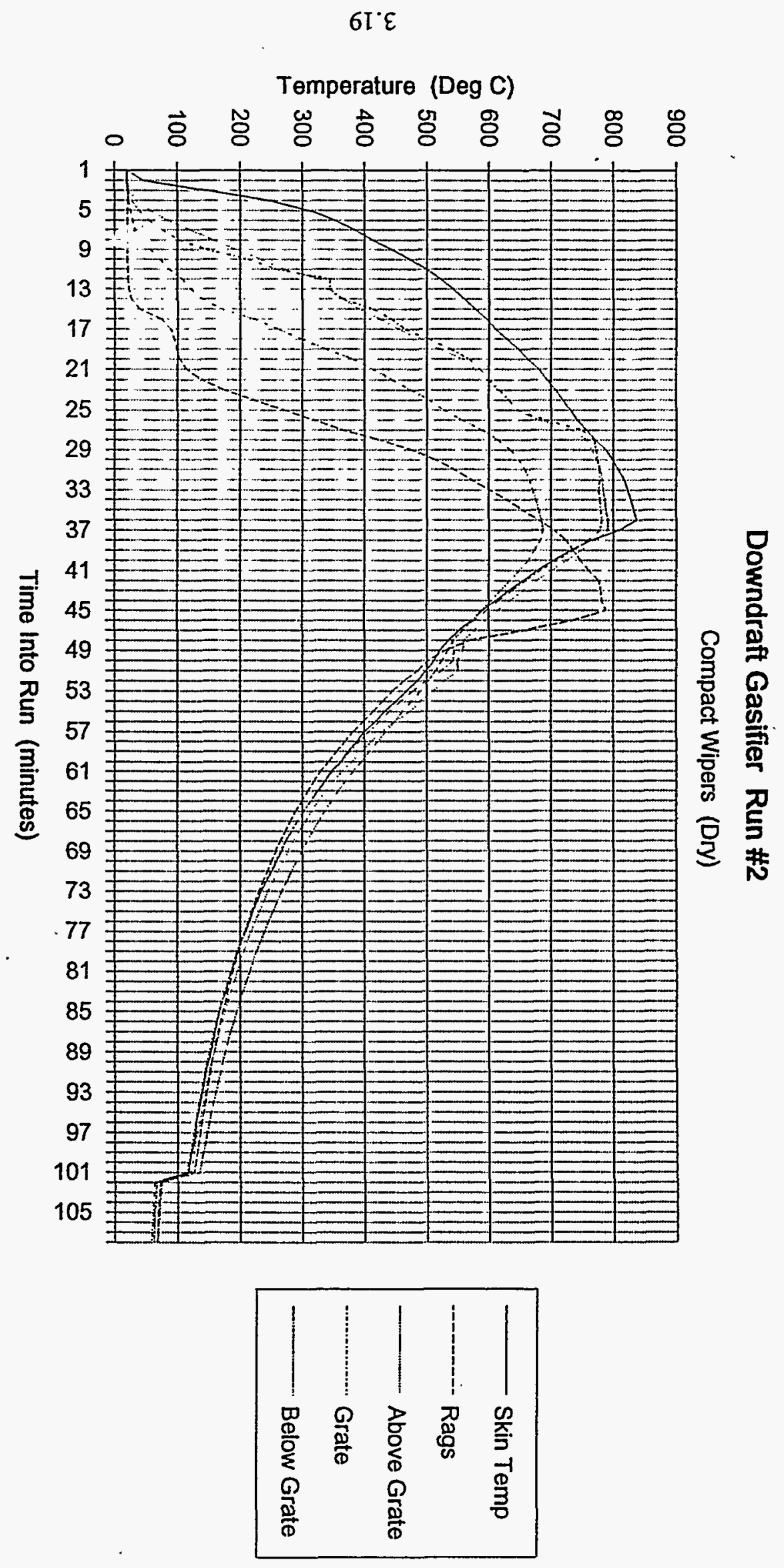



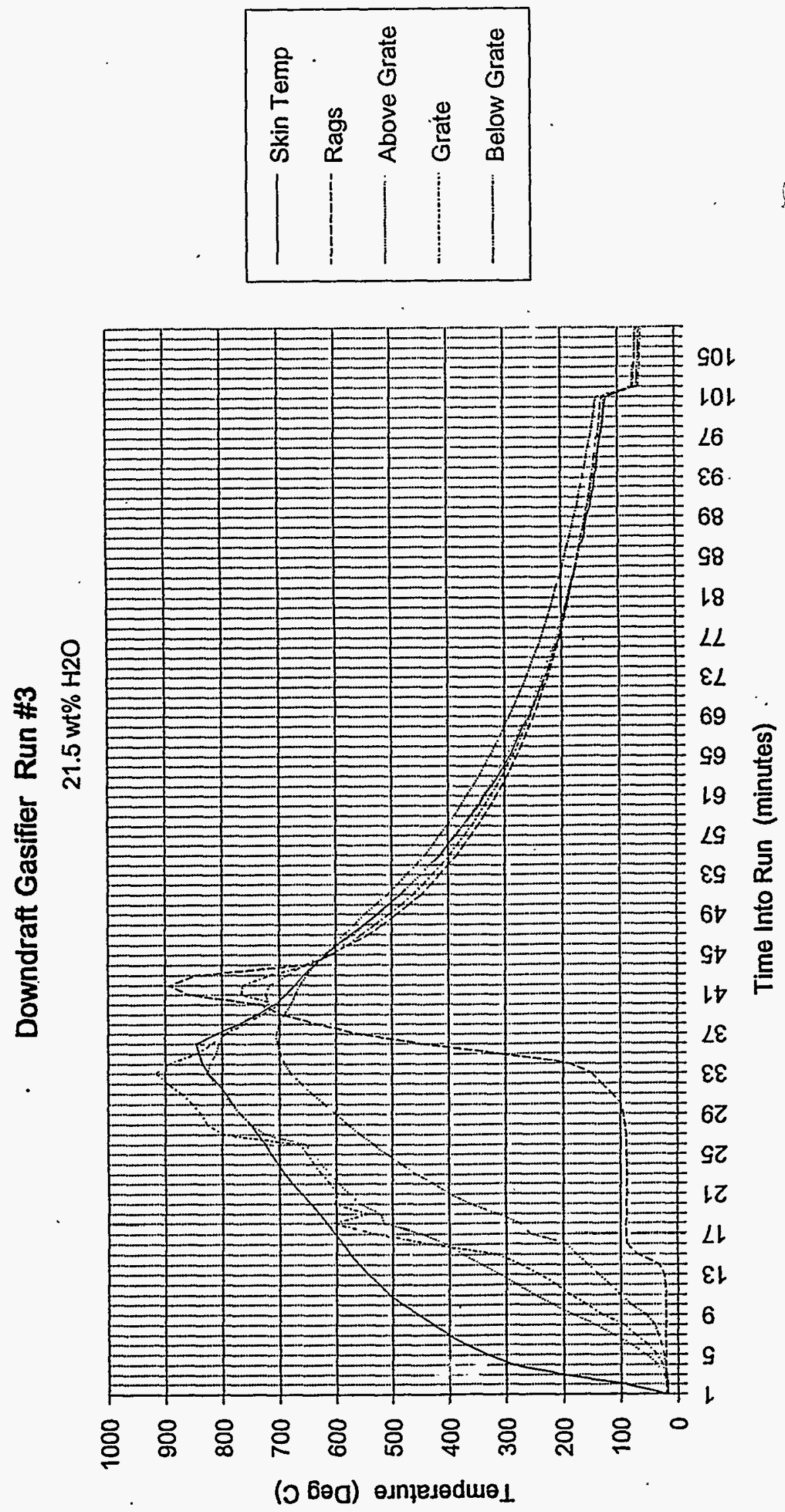

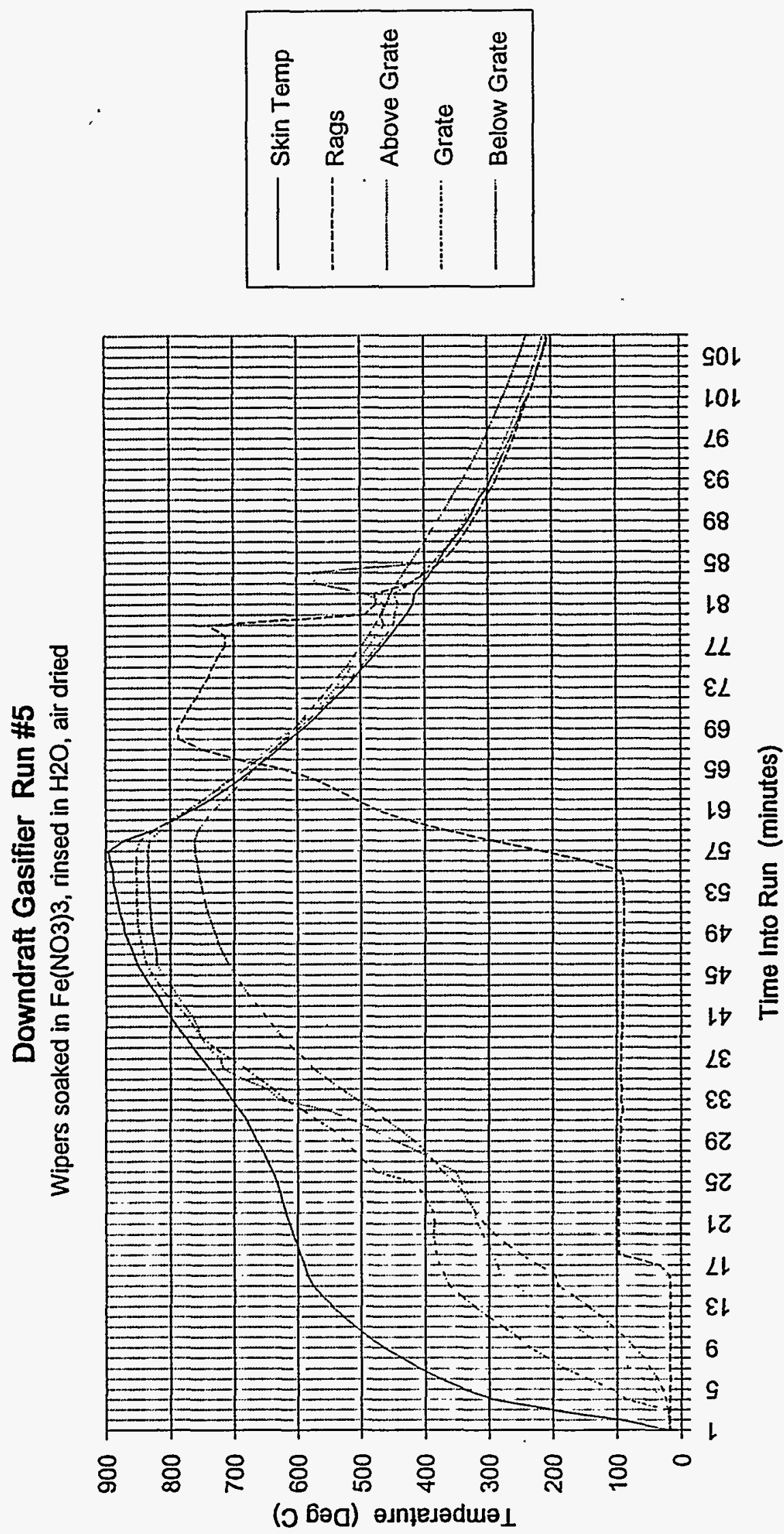


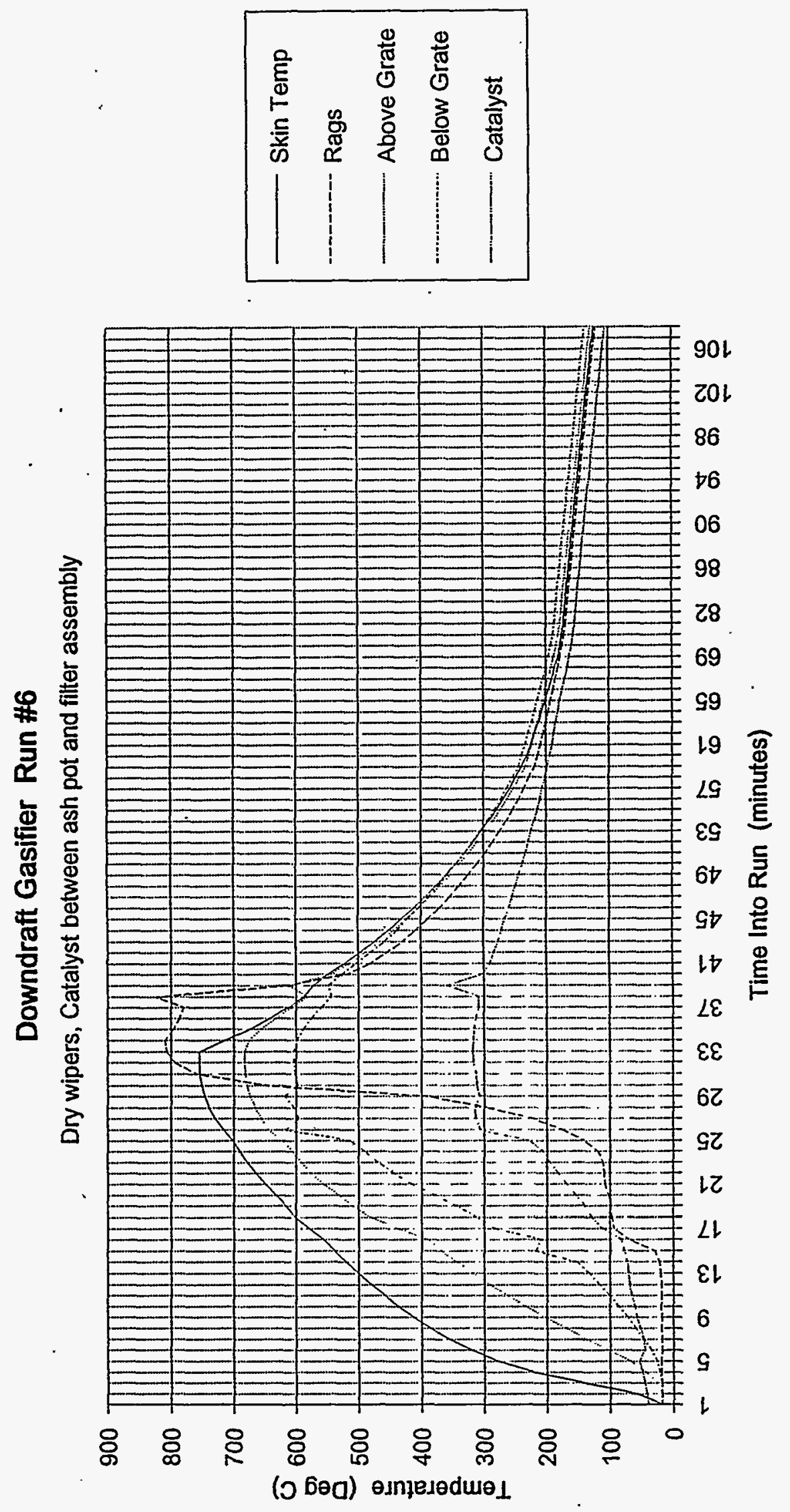



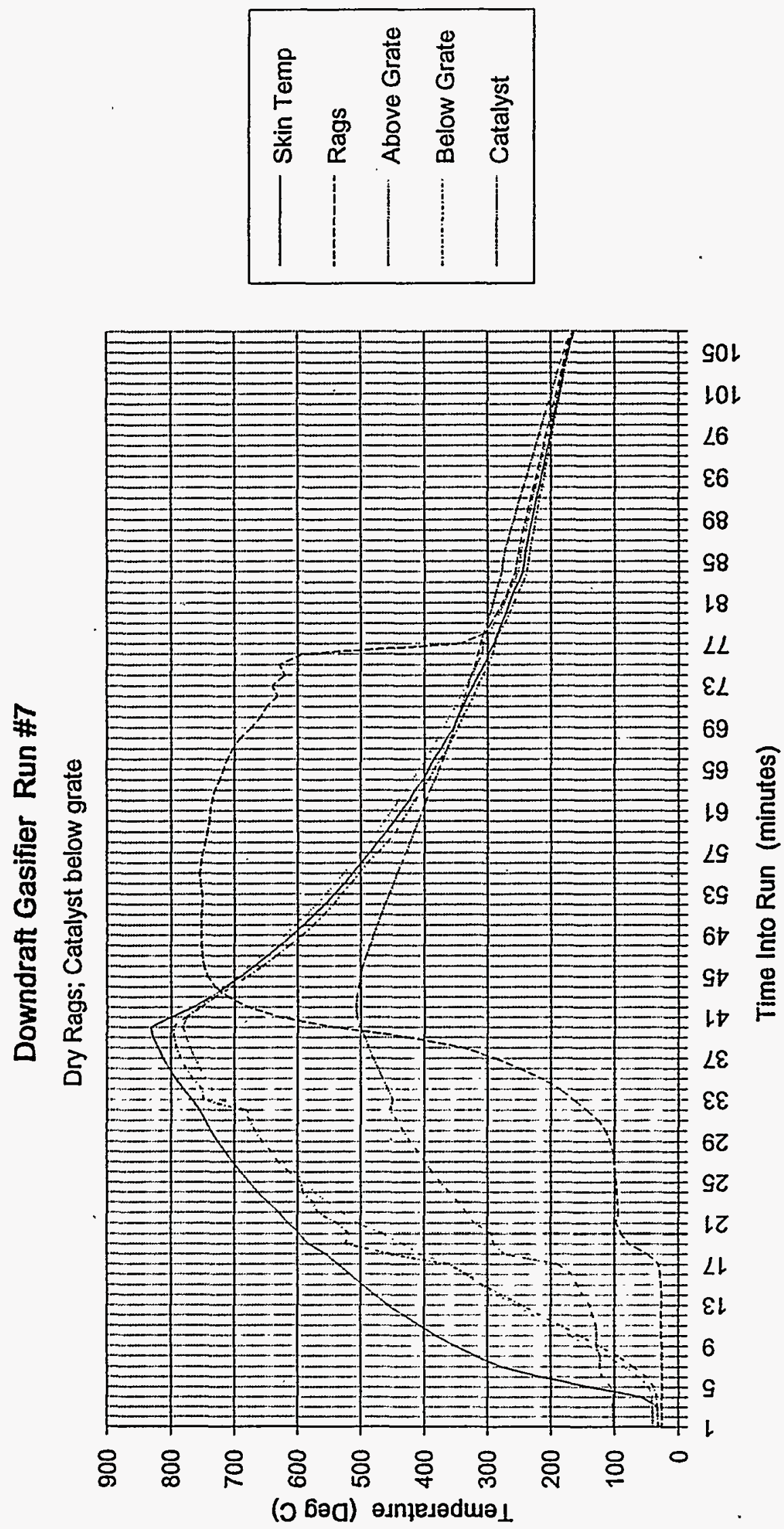

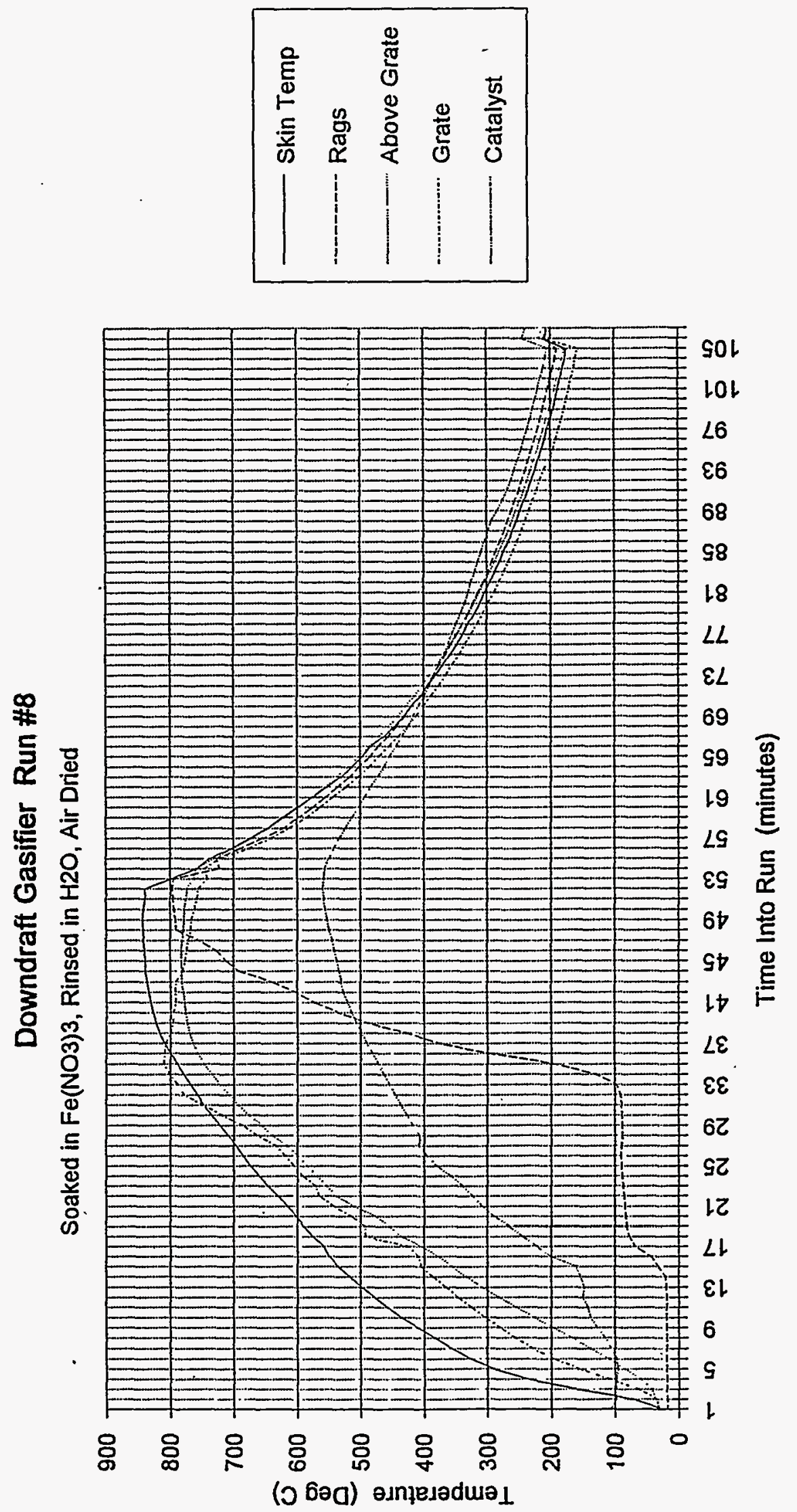


\subsection{Conclusions and Recommendations}

Results of this series of testing indicate that the potential for this type of thermal oxidation chamber is significant. Weight reductions of $150: 1$ were easily obtainable. With modifications, weight reductions of over 200:1 should be obtainable, with possible volume reductions of 500:1. Recommendations for increasing the efficiency of the system are noted as follows:

- The offgas leaving the main oxidation chamber is loaded with condensable tars. A hightemperature chamber located immediately after the main oxidation chamber could provide more complete thermal oxidation. The high-temperature chamber should be attached in such a manner as to prevent collection of tars and resins below the first stage of thermal oxidation.

- The offgas from the system should be analyzed for $\mathrm{NO}_{\mathrm{x}}$ and combustible gas emissions.

- An efficient thermal oxidation system might be useful in plutonium recovery and recycling processes from contaminated plastics and other combustible materials. A series of tests need to be conducted with materials other than $100 \%$ cotton to make further evaluations.

- The filters were wrapped in kaowool to prevent plugging due to excessive loading. The kaowool worked as desired; however, a better solution to the problem needs to be found. One solution might be to cover the filters with paint roller rolls that have a cardboard inner liner. The rolls could easily be installed and removed by a worker in a glove box situation. The loaded rollers could then be disposed of by thermal oxidation.

- A loading assembly needs to be added to the original design in order to test the thermal oxidation system in a continuous mode.

- Air inlet tubes need to be configured and attached to the oxidation chamber body in a different configuration. The original design results in leaks in the tubing where it is attached (welded) to the oxidation chamber wall. A better design would be to bend the tube into several alternating " $u$ " and " $n$ " shaped portions and attach the tubing with conduit straps on the vertical legs.

- Ash collects on the grate. In a continuous mode operation, it would not take long before the ash would collect to the point where operations would have to halt to clear the grate of ash. A method of agitating the grate surface to knock off any loose ash needs to be found: One possible solution is a mechanical arm that could sweep the surface of the grate and break the ash into finer particles. The arm should be operational from outside the oxidation chamber while the system is running.

- A series of tests need to be conducted with simulated PFP glove box wipers in a system modified to run on a continuous basis to make any further evaluations. 
